\title{
TumorSelect $\circledast$ Technology Enhancing the Safety and Efficacy of Cancer Chemotherapy
}

\section{Steve J. Bannister}

Cloaked Therapeutics, LLC

\section{Amir E. Wahba}

Damietta University

Mahesh Kumar Gundluru

Veiled Therapeutics, LLC

Igor Nikoulin

IriSys, LLC

Douglas L. Rodenburg

Veiled Therapeutics, LLC

Michael L. Coen

Prompt Praxis Laboratories, LLC

David A. Lewis

Prompt Praxis Laboratories, LLC

\section{Patrice Penfornis}

University of Mississippi Medical Center

Pier Paolo Claudio

University of Mississippi

James D. McChesney ( $\nabla$ jmcchesney@tumorselect.com )

Cloaked Therapeutics, LLC

\section{Research Article}

Keywords: Nanoparticles, pseudo-LDL, tumor targeting, prodrugs

Posted Date: July 20th, 2021

DOl: https://doi.org/10.21203/rs.3.rs-701601/v1

License: (1) This work is licensed under a Creative Commons Attribution 4.0 International License.

Read Full License 
3 Steve J. Bannister, $\mathrm{PhD}^{\mathrm{i}, \mathrm{ii}}$, Amir E. Wahba, PhD ${ }^{\mathrm{iii}, \mathrm{iv}}$, Mahesh Kumar Gundluru, PhD, Igor

4 Nikoulin, $\mathrm{PhD}^{\mathrm{v}}$, Douglas L. Rodenburg ${ }^{\mathrm{i}}$, Michael L. Coen, $\mathrm{MS}^{\mathrm{vi}}$, David A. Lewis, $\mathrm{PhD}^{\mathrm{vi}}$, Patrice

5 Penfornis ${ }^{\text {vii }}$, Pier Paolo Claudio, MD, PhD ${ }^{\text {viii }}$, James D. McChesney, PhD ${ }^{\mathrm{i}, \mathrm{ii}, \mathrm{ix}}$

\footnotetext{
${ }^{\mathrm{i}}$ Veiled Therapeutics, LLC, 147 County Road 245, Etta, MS 38627

${ }^{i i}$ Cloaked Therapeutics, LLC, 147 County Road 245, Etta, MS 38627

iii Department of Neurosurgery, Robert Wood Johnson Medical School, Rutgers University, 683 Hoes Lane West, Piscataway, NJ 08854

${ }^{\text {iv }}$ Chemistry Department, Faculty of Science, Damietta University, New Damietta City, 34518, Egypt

${ }^{v}$ IriSys, LLC, 6828 Nancy Ridge Drive, San Diego, CA 92121

${ }^{v i}$ Prompt Praxis Laboratories, LLC, 50 Lakeview Parkway, Suite 123, Vernon Hills, IL 60061

${ }^{v i i}$ School of Pharmacy - National Center for Natural Products Research

Cancer Center and Research Institute, University of Mississippi Medical Center, 2500 North State St., Jackson, MS 39216

viii National Center for Natural Products Research, Department of BioMolecular Sciences, Thad Cochran Research Center, University of Mississippi, Oxford, MS 38655

${ }^{\text {ix }}$ Corresponding author: jmcchesney @ tumorselect.com; Veiled Therapeutics, LLC, 147 County Road 245, Etta, MS 38627; (303) 808-4104
} 


\section{1. Abstract}

2 Veiled Therapeutics has developed an anticancer technology, TumorSelect ${ }^{\circledR}$ Technology, which

3 combines proprietary anticancer prodrugs and nanotechnology, which takes advantage from

4 current knowledge of human physiology. Tumors have a voracious appetite for cholesterol

5 which facilitates tumor growth and fuels their proliferation. We have transformed this need into

6 a stealth delivery system to disguise and deliver anticancer drugs with the assistance of both the

7 human body and the tumor cell. Veiled's designer prodrugs are assembled within pseudo-LDL

8 nanoparticulates which carry them to tumor tissues where they are taken up, internalized and

9 transformed into active drug and kill the cancer cells. This three-prong approach delivers the

10 anticancer drug selectively to the tumors and thereby avoids or reduces the severe side effect

11 toxicities associated with current chemotherapy. Reduction of side effect toxicity of cancer

12 therapy by our technology will improve patient quality of life, patient retention in treatment

13 regimes, more rapid patient recovery post treatment, and overall patient benefit.

\section{A. Background}

15 The costs of cancer, measured in terms of mortality, morbidity, direct costs of treatment, and 16 costs of lost productivity are high.

B. Methods

ART-207 was synthesized; a pseudo-LDL lipid nanodispersion was formed; and mouse xenograft studies were performed. 


\section{$1 \quad$ C. Results}

2 Preclinical toxicity, efficacy, and distribution data clearly show significant advantages of 3 TumorSelect $^{\circledR}$ paclitaxel over conventional Cremophor ${ }^{\circledR}$ formulations of paclitaxel. These 4 advantages include:

- Increased suppression of tumor growth and regrowth

- Lower toxicity

- Increased survival

- Higher number of tumor free animals

- Significantly lower concentrations of paclitaxel in non-target tissues

- Significantly higher concentrations of paclitaxel in tumor tissue

11 Thus, data obtained demonstrated targeted drug delivery and support LDL-receptor

12 dependent mechanism of selective cellular uptake by tumor tissue of TumorSelect ${ }^{\circledR}$

13 formulated paclitaxel.

\section{Conclusions}

15 Non-target tissue concentrations of paclitaxel are significantly lower in non-tumored and

16 tumored mice injected with formulated TumorSelect ${ }^{\circledR}$ paclitaxel compared with the mice 17 injected with Cremophor ${ }^{\circledR}$ EL/EtOH (ethanol) paclitaxel $(<20 \%)$. 
1 Tumor concentrations of paclitaxel are significantly higher in tumors of mice injected with

2 formulated TumorSelect ${ }^{\circledR}$ paclitaxel compared with the mice injected with Cremophor ${ }^{\circledR}$

3 EL/EtOH paclitaxel (194\%).

4 Plasma and heart concentrations of paclitaxel are significantly lower in tumored vs. non-

$5 \quad$ tumored animals injected with formulated TumorSelect ${ }^{\circledR}$ paclitaxel $(<80 \%)$.

6 Selective cellular uptake of TumorSelect ${ }^{\circledR}$ paclitaxel by tumors actively expressing LDL-

7 receptors has been demonstrated.

8 Tumor suppression observed was sustained for 63 days after Q1Dx5 dosing with

$9 \quad$ TumorSelect ${ }^{\circledR}$ paclitaxel.

10 TumorSelect $^{\circledR}$ technology represents a potential major improvement in the clinical treatment

11 of cancer through enhanced efficacy due to tumor-facilitated targeted delivery and reduced

12 patient toxicity with its associated deleterious side effects.

\section{2. Keywords}

14 Nanoparticles; pseudo-LDL; tumor targeting; prodrugs;

\section{3. Background}

\section{A. Costs of cancer}

17 Despite the availability of diverse pharmacological ${ }^{1}$ (as well as radiotherapeutic, ${ }^{2}$ and 18 surgical $^{3}$ ) cancer treatments, cancer remains a heterogeneous disease with many unmet 19 needs and is associated with very significant burdens measured in terms of morbidity, 20 mortality, direct costs of care, and indirect costs of productivity losses. In its 2020 Report 
on Cancer, the World Health Organization (WHO) reports that globally, in 2018, 9.6 million

2 people are estimated to have died of cancer and that cancer was the cause of one in six deaths. ${ }^{4}$ In its 2021 Cancer Facts and Figures Report, The American Cancer Society (ACS)

4 estimates that the United States will see nearly 2,000,000 million new cases of cancer in 52021 and over 600 thousand deaths due to cancer. ${ }^{5}$ In an assessment of US costs of cancer 6 care, based on US National Cancer Institute (NCI) data, the US Centers for Disease Control 7 and Prevention (CDC) estimates US costs of cancer care in 2020 to be $\$ 174$ billion. ${ }^{6}$ While 8 a precise estimate of 2020 indirect costs of cancer in the US could not be found, it is useful 9 to note that Jönsson, in 2019 stated, "indirect costs [in the European Union] related to the 10 loss of production for persons with cancer are estimated to be of the same magnitude as the 11 direct healthcare expenditures."7 If Jönsson's estimate of equivalence is applicable, it would 12 suggest that in the US in 2020 the combination of the direct costs of cancer care and the 13 costs of productivity lost to cancer morbidity and mortality approached $\$ 350$ billion.

\section{B. Recent development}

15 The enormous suffering and monetary costs of cancer are motivating significant progress in 16 the understanding of cancer biology and the discovery, development, and implementation of 17 new diagnostic tools, new drug therapies, and other new therapeutic modalities. In a recent 18 analysis of the advancements in cancer therapy in the five years ending mid $-2019,{ }^{8}$ the 19 characteristics of this progress are elaborated as: better understandings of tumor biology and 20 of the mechanisms of action of cancer therapies; and the increased use of precision 21 medicine. Advancements in cancer biology have led to a broad array of genomic ${ }^{9},{ }^{10},{ }^{11}$ and functional diagnostics ${ }^{12,13,14,15}$ that characterize a patient's susceptibility to a particular 23 cancer and a cancer's susceptibility to a particular treatment (the bases of precision 
$1 \quad$ medicine $\left.{ }^{16,17}\right)$

\section{Unmet needs}

Despite the significant progress that has been made in the development of cancer therapeutics there are still very significant unmet needs. The unmet needs have been enumerated: rare or unclassifiable tumors (no standard of care available), intractable tumor types (standard of care ineffective), intractable tumor subsets (no targeted treatments), intractable tumors (unexpectedly poor response to standard of care), and unfavorable benefit /risk ratio (high sensitivity to treatment toxicity). ${ }^{18}$

\section{Cytotoxic chemotherapy}

Cytotoxic cancer chemotherapeutics ${ }^{19,20,21}$ were the first drugs used to treat cancer $^{22}$ and despite the development and approval ${ }^{23,24,25}$ of other classes of cancer chemotherapeutics including immunotherapeutics, ${ }^{26,27}$ molecularly targeted therapeutics, ${ }^{28}$ and antihormone

agents, ${ }^{29}$ cytotoxics are very widely used. They are toxic to the rapidly dividing cells typical

of tumor tissues but are not highly selective and cause dose-limiting toxicities to rapidly

5 dividing normal tissues such as those of the bone marrow and the gastrointestinal tract. ${ }^{30}$

Cytotoxics are typically dosed at previously determined drug-specific maximum tolerated

7 doses $(\mathrm{MTD})^{31}$ so, by definition, their therapeutic indices (TI) ${ }^{32}$ are very low ${ }^{33}$ (slightly

8 greater than 1), whereas most non-oncology therapeutics have TI's of much greater than 10.

19 Recently developed (and approved for clinical use) biologic programmed death

20 1/programmed death ligand 1 (PD-1/PD-L1) checkpoint-blockade cancer immunotherapy

21 agents ${ }^{34,35}$ hold great promise but are only effective in a low percentage of patients. ${ }^{36,37,38}$ 
1 Recent studies have shown greater efficacy of these agents when co-dosed with cytotoxic

2 agents. ${ }^{39,40,41,42}$

\section{E. TumorSelect ${ }^{\circledR}$ technology $^{2}$}

The unmet needs outlined above might be addressed by a strategy that could deliver cytotoxic chemotherapeutics more selectively to tumors thereby shielding rapidly dividing normal systemic tissues from the ravaging side effects of the cytotoxic agents. Hundreds of thousands of cancer patients are treated each year with cytotoxic chemotherapeutic agents. A principal goal of chemotherapy drug development is to find strategies to make chemotherapeutics more selective and less toxic to normal tissues.

It was recognized decades ago that cancer patients (especially those with advanced disease) presented clinically with plasma lipid profiles significantly reduced in LDL concentration. ${ }^{43}$ This observation suggests a strategy to deliver drug to tumors taking advantage of their high uptake of lipids to support their rapid and continuous cell division and growth.

Tumors are voracious consumers of cholesterol and triglycerides both as an energy source and as substrates for membrane production of rapidly dividing cells. As a result, tumors dramatically overexpress LDL receptors by as much as eight-fold relative to healthy tissues. $^{44}$ Incorporating chemotherapeutics into pseudo-LDL nanoparticles for delivery via overexpressed LDL receptors on tumor cells provides the opportunity for selective delivery of lipophilic chemotherapeutics to tumors compared with normal tissues. Pseudo-LDL particles can increase the utility of clinically approved chemotherapeutic agents by altering their PK/PD properties and dramatically raising their therapeutic indices. 
$1 \quad$ TumorSelect $^{\circledR}$ is a delivery system designed for tumor-targeting delivery of drugs thereby

2 overcoming the low therapeutic index limitation. TumorSelect ${ }^{\circledR}$ includes a prodrug of

3 sufficient lipophilicity to be entrapped in a lipid nanoparticle of composition similar to that

4 of the lipid core of human LDL particles. Previous work by Maranhão and coworkers has

5 demonstrated that after injection such a pseudo-LDL nanoparticle lipid nanoparticle adsorbs

6 a molecule of exchangeable apo-lipoprotein, the ligand which mediates internalization of the

7 particle by the LDL receptors (LDLR) that are overexpressed by rapidly dividing tumor

8 cells. $^{45,46,47}$ This biological phenomenon is the rationale for TumorSelect ${ }^{\circledR}$ chemotherapeutic

9 delivery technology.

10 As a proof of concept of the technology, paclitaxel, a very widely clinically utilized

11 cytotoxic chemotherapeutic, was selected for evaluation for selective delivery via

12 TumorSelect ${ }^{\circledR}$ delivery.

13 The work described in this manuscript characterizes the preclinical performance of

14 TumorSelect ${ }^{\circledR}$ technology applied to the delivery of paclitaxel to demonstrate selective

15 delivery to tumors and thereby enhance its efficacy and reduce its toxicity.

16 Four questions were addressed:

1. Can a pseudo-LDL nanoparticle be created which is sufficiently similar to natural human LDL particles to be physiologically recognizable and stable enough to serve as a delivery vehicle for a cytotoxic payload?

2. Can a suitable paclitaxel derivative be prepared to be efficiently incorporated into the delivery formulation? 
3. Does the proposed TumorSelect ${ }^{\circledR}$ construct of cytotoxic derivative and delivery vehicle improve TI of the cytotoxic and still retain efficacy?

4. Does the TumorSelect ${ }^{\circledR}$ technology selectively deliver cytotoxic to tumor tissue as proposed?

Paclitaxel was chosen as the model for these development efforts as it is active in treatment of numerous solid tumor types including: breast, ovarian, lung, esophageal, pancreatic, prostate, melanoma, bladder, Kaposi's sarcoma, and other types of solid tumors. Current paclitaxel therapy is limited by toxicity and resistance development. Commonly seen toxicities include: leukopenia and neutropenia; nausea, vomiting, and diarrhea; hair loss; peripheral neuropathy; hypersensitivity reactions; mouth sores; and arthralgias and myalgias. Clinical utility of current paclitaxel therapy is limited by development of resistance on the part of the tumors by expression of paclitaxel efflux by $\mathrm{ABC}$ transporters (P-glycoprotein (Pgp), breast cancer resistance protein (BCRP), multi-drug resistance related protein (MRP-1)), expression of mutated B1 tubulin and aberrant tubulin isoforms, and enhanced expression of cell survival mechanisms. ${ }^{48}$

In order to incorporate the current clinically approved chemotherapeutic into the pseudoLDL particle, the hydrophilic chemotherapeutic was converted to a lipophilic acid-labile prodrug which is capable of being retained within the pseudo-LDL particle until the particle is internalized into the tumor cells by uptake by the LDL receptor and processed by the endosome/lysosome cascade, ultimately releasing the active chemotherapeutic drug moiety. This strategy is directly applicable to the majority of clinically approved and widely utilized chemotherapeutics. 


\section{Materials and methods}

2 To address question one - preparation of a pseudo-LDL delivery formulation vehicle we

3 undertook efforts to prepare such a material via the technique of microfluidization.

\section{A. Pseudo-LDL nanoparticle dispersion preparation}

The TumorSelect ${ }^{\circledR}$ lipid nanoparticle formulation was prepared through extensive development efforts as previously described. ${ }^{49}$

\section{i. Homogenization}

Quantities of the components which make up the nanoparticles (dispersed in $0.9 \% \mathrm{NaCl}$ in $10 \mathrm{mM}$ Acetate buffer, pH 5.5) of TumorSelect ${ }^{\circledR}$ paclitaxel are shown in Table 1 below. 
Table 1 Composition of TumorSelect ${ }^{\circledR}$ paclitaxel nanoparticles

\begin{tabular}{|c|c|c|c|}
\hline Ingredients & $\begin{array}{l}\mathrm{mg} / \mathrm{mL} \text { in } \\
\text { dispersion }\end{array}$ & $\begin{array}{l}\% w / w \\
\text { in solids }\end{array}$ & Notes \\
\hline $\begin{array}{l}\text { Egg Yolk Phosphatidylcholine } \\
\text { (PC) } \\
\text { Lipoid, GMBH }\end{array}$ & 42.5 & 59.1 & $\begin{array}{l}\text { Principal surfactant; } \\
\text { mixture of fatty-acid } \\
\text { diesters of } \\
\text { glycerophosphocholine } \\
\text { similar to that found in } \\
\text { human LDL }\end{array}$ \\
\hline $\begin{array}{l}\text { Dimyristoylphosphocholine } \\
\text { (DMPC) } \\
\text { Avanti Polar Lipids, Inc. }\end{array}$ & 11.2 & 15.6 & $\begin{array}{l}\text { Secondary surfactant; a } \\
\text { specific diester of } \\
\text { glycerophosphocholine; } \\
\text { shorter fatty acids than } \\
\text { those found in egg yolk PC }\end{array}$ \\
\hline $\begin{array}{l}\text { Soybean Oil (TG) } \\
\text { Crisco }\end{array}$ & 7.4 & 10.2 & $\begin{array}{l}\text { Triglyceride mixture in core } \\
\text { of lipid particle; similar to } \\
\text { that found in human LDL }\end{array}$ \\
\hline ART-207 & 5.4 & 7.6 & $\begin{array}{l}\text { Prodrug payload; equivalent } \\
\text { to } 3.78 \mathrm{mg} \text { paclitaxel per } \mathrm{mL}\end{array}$ \\
\hline $\begin{array}{l}\text { Poloxamer P188 (P188) } \\
\text { Spectrum Chemicals }\end{array}$ & 3.0 & 4.2 & $\begin{array}{l}\text { Secondary surfactant and } \\
\text { surface modifier }\end{array}$ \\
\hline $\begin{array}{l}\text { Cholesterol Oleate (CE) } \\
\text { Alfa Aesar }\end{array}$ & 1.5 & 2.1 & $\begin{array}{l}\text { Cholesterol ester found in } \\
\text { particle core and in human } \\
\text { LDL }\end{array}$ \\
\hline $\begin{array}{l}\text { Cholesterol 95\% (FC) } \\
\text { Alfa Aesar }\end{array}$ & 0.7 & 0.97 & $\begin{array}{l}\text { Lipid in particle core and in } \\
\text { human LDL }\end{array}$ \\
\hline $\begin{array}{l}\text { Ubiquinol } 10(\mathrm{U}) \\
\text { Kaneka Corpor }\end{array}$ & 0.1 & 0.14 & $\begin{array}{l}\text { Antioxidant found in human } \\
\text { LDL }\end{array}$ \\
\hline $\begin{array}{l}\text { Mixed Tocopherols (VitE) } \\
\text { Swanson }\end{array}$ & 0.1 & 0.14 & $\begin{array}{l}\text { Antioxidant mixture } \\
\text { including } \alpha \text {-tocopherol } \\
\text { found in human LDL }\end{array}$ \\
\hline Sum & 71.9 & 100 & \\
\hline
\end{tabular}

The target amounts of formulation components (PC, DMPC, TG, FC, CE, U and Vit E) were weighed into a suitably sized beaker to form a lipid premix (LPM). The target a warm water bath with gentle agitation with nitrogen flow. Once the DCM had evaporated, the $\mathrm{LPM}$ was held in $45^{\circ} \mathrm{C}$ vacuum oven at $100 \mu \mathrm{m}$ for at least 1 hour to 
remove residual DCM. The LPM was stored at $-5^{\circ} \mathrm{C}$ prior to high-pressure homogenization.

The LPM was removed from the freezer and allowed to warm to RT; $100 \mathrm{~mL}$ of formulation buffer $\left(0.9 \% \mathrm{NaCl}\right.$ in $10 \mathrm{mM}$ Acetate buffer of $\mathrm{pH} 5.5$ at $\left.65^{\circ} \mathrm{C}\right)$ was added and the mixture was homogenized with a hand blender with short pulses for 1 to 2 minutes to form a coarse emulsion. The coarse emulsion was transferred to a MicroFluidizer (MF) (MicroFluidics, Inc., Model 110P with temperature-controlled recirculation bath) and processed at $30,000 \mathrm{psi}$ and $60^{\circ} \mathrm{C}$, monitoring particle size of processed material at 10 minutes intervals by dynamic light scattering until an intensityweighted mean particle size of less than $65 \mathrm{~nm}$ was achieved. The nanoparticle dispersion was sterile filtered through a $0.22-\mu \mathrm{m}$ polyethersulfone polymer membrane filter.

\section{ii. Characterization of nanoparticle dispersions}

The HPLC analytical method used to quantitate ART 207 in lipid emulsions was performed on an Agilent 1100 quaternary pump and single wavelength system. The column was a Phenomenex 4.6 x 50 mm Luna $5 \mu \mathrm{m}$ C18(2) $100 \AA$, part number 00B4252-E0. The method conditions were: flow rate: $1.5 \mathrm{~mL} /$ minute, detection: $230 \mathrm{~nm}$, column temperature: $55^{\circ} \mathrm{C}$, and injection volume: $3 \mu \mathrm{L}$. The gradient program is shown in Table 2 below.

Table 2 Reverse-phase HPLC gradient

\begin{tabular}{|c|c|c|}
\hline Time, minutes & \% Acetonitrile & $\frac{\% 0.01 \mathrm{M} \text { aqueous }}{\underline{\mathrm{H}}_{3} \underline{\mathrm{PO}}_{4}}$ \\
\hline
\end{tabular}




\begin{tabular}{|c|c|c|}
\hline 0 & 75 & 25 \\
\hline 7 & 100 & 0 \\
\hline 9 & 100 & 0 \\
\hline 10 & 75 & 25 \\
\hline 11 & 75 & 25 \\
\hline
\end{tabular}

Intensity-weighted mean particle sizes were determined by dynamic light scattering using a Nicomp Model 380 ZLS Zeta Potential/Particle Sizer from Particle Sizing Systems.

\section{B. ART-207 synthesis}

Discovery of a suitable cytotoxic derivative for incorporation (answering question 2 above) into the pseudo-LDL nanoparticle delivery vehicle recognized the derivative must be

8 lipophilic, would readily release active cytotoxic moiety upon delivery to tumor tissue and

9 be readily accessible via chemical synthesis.

11 reaction sequence is shown in Figure 1 below. 


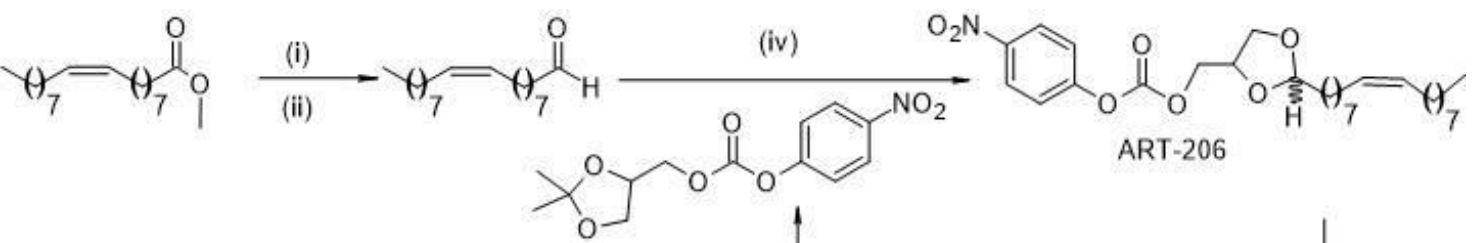<smiles>CC1(C)OCC(CO)O1</smiles>

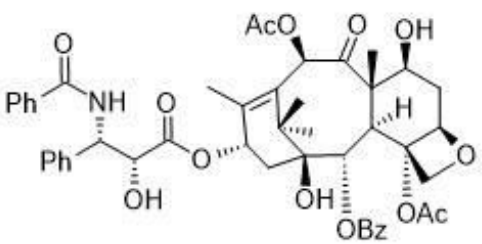

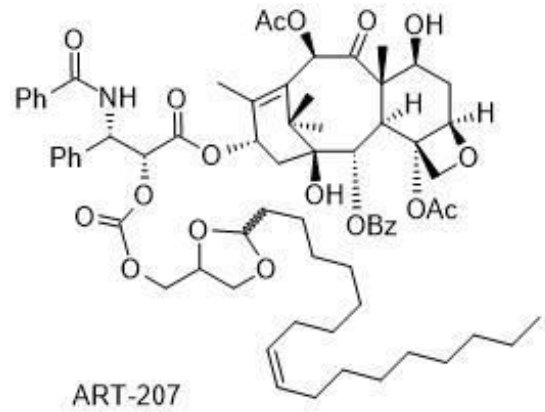

paclitaxel

3 The reactions are described in Table 3 below.

Table 3 Synthesis of ART-207

\begin{tabular}{|c|c|c|c|}
\hline Step & Reaction & Solvent & $\begin{array}{c}\text { Purification by } \\
\text { normal-phase } \\
\text { chromatography }\end{array}$ \\
\hline i & $\begin{array}{c}\text { methyl oleate is reduced to oleyl } \\
\text { alcohol with 4 mole equivalents of } \\
\text { diisobutylaluminium hydride } \\
\text { (DIBAL-H) }\end{array}$ & n-heptane & No \\
\hline ii & $\begin{array}{c}\text { oleyl alcohol is oxidized to oleyl } \\
\text { aldehyde under with 1.2 } \\
\text { equivalents of Dess-Martin } \\
\text { periodinane (1,1,1-Tris(acetyloxy)- } \\
\text { 1,1-dihydro-1,2-benziodoxol-3- } \\
\text { (1H)-one }\end{array}$ & dichloromethane & Yes \\
\hline iii & $\begin{array}{c}\text { Solketal is reacted with 4- } \\
\text { nitrophenylchloroformate and } \\
\text { pyridine (1.2 mol equivalent) } \\
\text { catalyzed by dimethylpyridine } \\
\text { (DMAP), to form the 4-nitrophenyl } \\
\text { carbonate-solketal conjugate }\end{array}$ & dichloromethane & Yes \\
\hline \multicolumn{2}{|c|}{} & \\
\hline
\end{tabular}




\begin{tabular}{|c|c|c|c|}
\hline iv & $\begin{array}{c}\text { The 4-nitrophenyl carbonate- } \\
\text { solketal conjugate is reacted with } \\
\text { oleyl aldehyde catalyzed by } p- \\
\text { toluenesulfonic acid ( } \mathrm{p}-\mathrm{TsOH} \text { ) in } \\
\text { toluene to form ART-206 }\end{array}$ & toluene & Yes \\
\hline$v$ & $\begin{array}{c}\text { ART-206 is reacted with paclitaxel } \\
\text { and DMAP (1.5 equivalents) to } \\
\text { form ART-207 }\end{array}$ & dichloromethane & Yes \\
\hline
\end{tabular}

\section{Biological Evaluation}

Accepted in vivo animal models were selected to demonstrate TumorSelect ${ }^{\circledR}$ technology's potential.

\section{i. ATL-1 and 2}

To assess the toxicity and, preliminarily, the efficacy of TumorSelect ${ }^{\circledR}$ paclitaxel, two small studies were commissioned at Southern Research Institute, Birmingham, AL USA.

\section{a. Experiment ATL-1} formulation. 
were administered intravenously (IV) once a day for five consecutive days (Q1Dx5) beginning on Day 1. Thus, the total dose of drug administered was 5 times the dose injected per injection. Animals in Groups 1-4 were treated with formulated ART 207 at doses of 72.6, 47.1, 35.7, and $23.7 \mathrm{mg} / \mathrm{kg} /$ injection, respectively, administered to the mice by exact individual animal's body weight on each day of treatment with the injection volume being $0.21 \mathrm{~mL} / 20 \mathrm{~g}$ of body weight. The formulated ART 207 doses of 72.6, 47.1, 35.7, and $23.7 \mathrm{mg} / \mathrm{kg}$ were $3.4 x, 2.2 x, 1.7 x$, and 1.1x molar equivalent of a paclitaxel dose of $15 \mathrm{mg} / \mathrm{kg}$, respectively, based on the molecular weight of formulated ART 207 of 1220.4 and molecular weight of paclitaxel of 853.9. Animals in Group 5 (Emulsion control) were treated with a drug free formulation (injection volume of $0.21 \mathrm{~mL} / 20 \mathrm{~g}$ of body weight). Animals in Group 6 were treated with paclitaxel at a dose of 15 $\mathrm{mg} / \mathrm{kg} /$ injection (injection volume of $0.1 \mathrm{~mL} / 10 \mathrm{~g}$ of body weight). (In this particle experiment, the $15 \mathrm{mg} / \mathrm{kg}$ paclitaxel dose proved toxic to 4 of the 5 mice of the paclitaxel group.)

\section{b. Experiment ATL-2}

This study was commissioned to assess preliminary efficacy of the TumorSelect ${ }^{\circledR}$ paclitaxel.

The study consisted of six groups of five mice per group for a total of 30 mice bearing human MDA-MB-231 mammary tumor on the first day of treatment, Day 13 after tumor fragment implantation (January 22, 2013). All treatments were administered IV on a Q1Dx5 schedule beginning on Day 13. Animals in Groups 1- 
4 were treated with formulated ART 207 at doses of 72.6, 47.1, 35.7, and 23.7 $\mathrm{mg} / \mathrm{kg} /$ injection, respectively, administered to the mice by exact individual animal's body weight with the injection volume being $0.21 \mathrm{~mL} / 20 \mathrm{~g}$ of body weight. The formulated ART 207 doses of 72.6, 47.1, 35.7, and $23.7 \mathrm{mg} / \mathrm{kg}$ were $3.4 x, 2.2 x, 1.7 x$, and 1.1x molar equivalent of a paclitaxel dose of $15 \mathrm{mg} / \mathrm{kg}$, respectively, based on the molecular weight of formulated ART 207 of 1220.4 and molecular weight of paclitaxel of 853.9. Animals in Group 5 (Emulsion control) were treated with a drug-free formulation (injection volume of $0.21 \mathrm{~mL} / 20 \mathrm{~g}$ of body weight). Animals in Group 6 were treated with paclitaxel at a dose of 15 $\mathrm{mg} / \mathrm{kg} /$ injection (injection volume of $0.1 \mathrm{~mL} / 10 \mathrm{~g}$ of body weight).

\section{c. ATL-3 Mouse breast-cancer xenograft safety and efficacy study}

The purpose of the experiment ATL-3 (contracted for execution at Southern Research Institute, Birmingham, AL) was to evaluate and confirm the antitumor activity of the intravenous (IV) treatment with TumorSelect ${ }^{\circledR}$ paclitaxel when administered to female, athymic NCr-nu/nu mice implanted subcutaneously (SC) with human MDA-MB-231 mammary tumor xenografts and also to provide an indication of experimentally tolerated dose of TumorSelect ${ }^{\circledR}$ paclitaxel in murine models. Paclitaxel formulated in 50/50 Cremophor ${ }^{\circledR}$ EL/ethanol was included as a reference treatment. ATL 4\&5 Mouse breast-cancer xenograft drug distribution studies

The purpose of the experiments ATL- 4 and ATL-5 was to determine the concentration of ART 207 and paclitaxel in plasma, brain, heart, liver, lungs, and 
tumor (experiment ATL-5 only) after a single intravenous (IV) injection of formulated ART 207 or paclitaxel to non-tumored female athymic $\mathrm{NCr}-n u / n u$ mice and female athymic NCr-nu/nu mice bearing a subcutaneous (SC) human MDAMB-231 mammary tumor.

Plasma and tissue concentrations of paclitaxel were determined with a modification of a previously published LC-MS/MS method. ${ }^{51}$ Quantitative determination of Paclitaxel in mouse plasma or tissue homogenate was accomplished by protein precipitation and high-performance liquid chromatography with tandem mass spectrometric detection (LC-MS/MS). ${ }^{13} \mathrm{C}_{6}$-paclitaxel was used as the internal standard (IS). Paclitaxel and IS were extracted from $50 \mu \mathrm{L}$ mouse plasma or tissue homogenate by protein precipitation using acetonitrile. The chromatographic separation was achieved using an Ace $3 \mathrm{C}_{18}$ analytical column maintained at $40^{\circ} \mathrm{C}$ under gradient conditions. Column effluents were analyzed by multiple-reaction monitoring (MRM) using a triple quadrupole mass spectrometer in positive-ion mode (AB Sciex 4000 Q Trap LC/MS/MS system, equipped with TurboV IonSpray ${ }^{\circledR}$ ). The precursor/product transitions are $876.3 \rightarrow 308.2 \mathrm{~m} / \mathrm{z}$ for paclitaxel and $882.4 \rightarrow 313.9 \mathrm{~m} / \mathrm{z}$ for $13 \mathrm{C} 6$-paclitaxel. The calibration curve was fit using weighted $\left(1 / \mathrm{x}^{2}\right)$ linear regression analysis of the paclitaxel/IS peak area ratio versus the paclitaxel concentration from $5.00-5,000 \mathrm{ng} / \mathrm{mL}$. Concentrations of incurred and quality control samples were calculated with the same regression analysis and results were reported in $\mathrm{ng} / \mathrm{mL}$ or $\mathrm{ng} / \mathrm{g}$ of paclitaxel.

Tumored mice were subdivided into 5 groups ( 3 mice per each group). All mice were bolus injected intravenously with either $70 \mathrm{mg} / \mathrm{kg}(49 \mathrm{mg} / \mathrm{kg}$ paclitaxel 
equivalent) of TumorSelect ${ }^{\circledR}$ paclitaxel or $18.9 \mathrm{mg} / \mathrm{kg}$ of Chemophor ${ }^{\circledR} / \mathrm{ethanol}$ formulated paclitaxel (the MTD for single bolus injection). Blood samples and organs were collected at 5, 30, 60, 240, and 480 min after single bolus injection. Each time point represents 3 mice.

Quantitative determination of ART-207 in mouse plasma and tissue homogenate was accomplished by protein precipitation and high-performance liquid chromatography with tandem mass spectrometric detection (LC-MS/MS). ${ }^{13} \mathrm{C}_{6}$ ART-207 was used as the internal standard. ART-207 and IS were extracted from $50 \mu \mathrm{L}$ mouse plasma or tissue homogenate by protein precipitation using acetonitrile. The chromatographic separation was achieved using an Ace $3 \mathrm{C}_{18}$ analytical column maintained at $40{ }^{\circ} \mathrm{C}$ under isocratic conditions. Column effluents were analyzed by multiple-reaction monitoring (MRM) using a triple quadrupole mass spectrometer in positive-ion mode (AB Sciex 4000 Q Trap LC/MS/MS system, equipped with TurboV IonSpray). The precursor/product transitions are $1220.7 \rightarrow 652.5 \mathrm{~m} / \mathrm{z}$ for ART-207 and $1226.7 \rightarrow 658.5 \mathrm{~m} / \mathrm{z}$ for ${ }^{13} \mathrm{C}_{6}$ ART-207. The calibration curve was fit using weighted $\left(1 / \mathrm{x}^{2}\right)$ linear regression analysis of the ART-207/IS peak area ratio versus the ART-207 concentration from $5.00-500 \mu \mathrm{g} / \mathrm{mL}$. Concentrations of incurred and quality control samples were calculated with the same regression analysis and results were reported in $\mu \mathrm{g} / \mathrm{mL}$ or $\mu \mathrm{g} / \mathrm{g}$ of ART-207.

Tissue exposure is expressed as the area under the concentration-time curve (AUC) from 0 to the last time point at which the analyte was measured $(8 \mathrm{hrs})$. Areas under the mean concentration-time curve from 0 to eight hours $\left(\mathrm{AUC}_{0-8}\right)$ were 
calculated as previously described. ${ }^{52}, 53$

\section{ii. Mouse pancreatic tumor xenograft study}

As a second comparison in vivo study, the pancreatic tumor cells MIA-PaCa-2 (ATCC, Manassas, VA) was implanted in NOD scid (NSG) female mice, and the animals were dosed with TumorSelect ${ }^{\circledR}$ paclitaxel with a comparison positive control of Abraxane ${ }^{\circledR}$. Female, six-week-old, NOD.CG-PRKDC ${ }^{\mathrm{SCID}}$ Il2RG $\mathrm{RM}^{\mathrm{TM} 1 \mathrm{WJ}} / \mathrm{SZJ}$ mice known as NOD scid gamma mice (NSG 005557, Jackson Lab) were purchased from Jackson Laboratories (Bar Harbor, ME) and acclimated at the laboratory animal facility at the University of Mississippi Medical Center (Jackson, MS). All animals were housed in microisolator cages, up to five per cage, in a 12-hour light/dark cycle. The animals received filtered water and irradiated Teklad rodent diet (LM-7945, Envigo Inc.) ad libitum. No consumable enrichment was provided. Cages were changed twice weekly. The animals were observed daily and clinical signs were noted. At 8 weeks of age mice were injected in the flank with $10^{6}$ MIA-paca-2 human cells (ATCC, Manassas, VA) with $100 \mathrm{uL}$ Matrigel (Corning). Tumor development was measured using an electronic caliper every 2 or 3 days through up to 105 days. The formula used for tumor volume calculation is

$$
\text { Tumor volume }=\frac{4}{3} \pi\left(\frac{W}{2}\right)^{2}\left(\frac{L}{2}\right)
$$

where: Tumor volume is expressed in $\mathrm{mm}^{3} ; W$ is width (the shorter dimension) in $\mathrm{mm}$; and $L$ is length (the longer dimension) in $\mathrm{mm}$. Mouse weights were measured every 2 or 3 days. 
Beginning on day 24 after implantation (when the tumors reached $200-250 \mathrm{~mm}^{3}$ ), the mice were divided into three groups and were injected daily with Abraxane $(15 \mathrm{mg} / \mathrm{kg}$ paclitaxel equivalent), TumorSelect vehicle, or TumorSelect paclitaxel $(37.5 \mathrm{mg} / \mathrm{kg}$ paclitaxel equivalent) for 5 consecutive days (total Abraxane paclitaxel dose of 75 $\mathrm{mg} / \mathrm{kg}$, total TumorSelect paclitaxel dose of . Total Abraxane dose of $75 \mathrm{mg} / \mathrm{kg}$ and formulated ART- 207 dose of $187.5 \mathrm{mg} / \mathrm{kg}$ for a paclitaxel equivalent dose of 132.5 $\mathrm{mg} / \mathrm{kg}$.)

\section{Results}

\section{A. Material characterization}

The ART-207 content and mean particle-size data for TumorSelect ${ }^{\circledR}$ paclitaxel nanoparticle dispersions used in animal studies are shown in Table 4 below.

Table 4 Particle-size characterization of TumorSelect ${ }^{\circledR}$ paclitaxel nanoparticles

\begin{tabular}{|c|c|c|c|c|c|}
\hline \multirow[b]{2}{*}{ Lot\# } & \multirow[b]{2}{*}{$\begin{array}{l}\text { Used in } \\
\text { study }\end{array}$} & \multirow{2}{*}{$\begin{array}{l}\text { Intensity- } \\
\text { weighted } \\
\text { mean } \\
\text { particle } \\
\text { size, nm }\end{array}$} & \multirow{2}{*}{$\begin{array}{c}\text { ART-207 } \\
\mathrm{mg} / \mathrm{mL}\end{array}$} & \multicolumn{2}{|c|}{$\begin{array}{c}\text { Particle size } \\
\text { stability }\end{array}$} \\
\hline & & & & $\begin{array}{l}\text { Days } \\
\text { past } \\
\mathrm{mfg}\end{array}$ & $\begin{array}{c}\text { Particle } \\
\text { size } \\
n m\end{array}$ \\
\hline 002.151 .8 & ATL-3 & 62 & 5.26 & 42 & 67 \\
\hline 002.156 .3 & ATL-4\&5 & 62 & 4.80 & 39 & 61 \\
\hline 06292018 & $\begin{array}{l}\text { Pancreatic } \\
\text { xenograft }\end{array}$ & 73 & 4.81 & 180 & 77 \\
\hline
\end{tabular}

\section{B. Biological evaluation}

The results of the mouse safety, pharmacokinetics, and efficacy studies are shown below. In all displays, doses are expressed in paclitaxel equivalents. 


\section{i. ATL-3 Breast-cancer mouse xenograft safety and efficacy study}

The following graphs show animal survival, animal weights, and tumor weights in the

breast-cancer mouse xenograft study. In all figures the TumorSelect ${ }^{\circledR}$ and Cremophor ${ }^{\circledR}$ administered doses are expressed in paclitaxel equivalents per injection which provides a total of 5-times the daily injection for the experimental drug exposure.

\section{a. Animal survival data}

The survival of animals in Study ATL-3 is illustrated in Figure 2 below. 


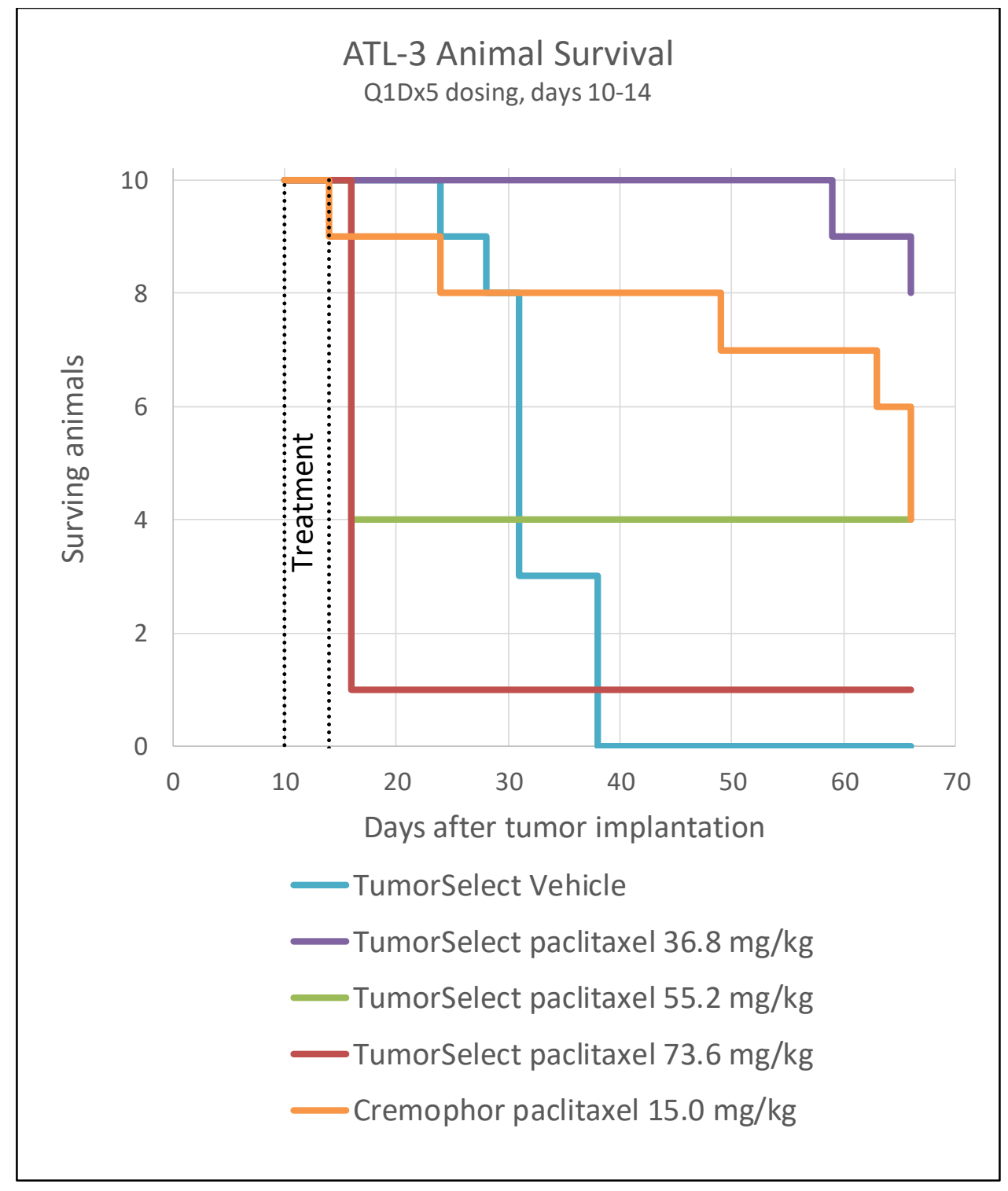

Figure 2 Animal survival in ATL-3

b. Mean animal weights

The mean animal weights in Study ATL-3 are illustrated in Figure 3 below. 


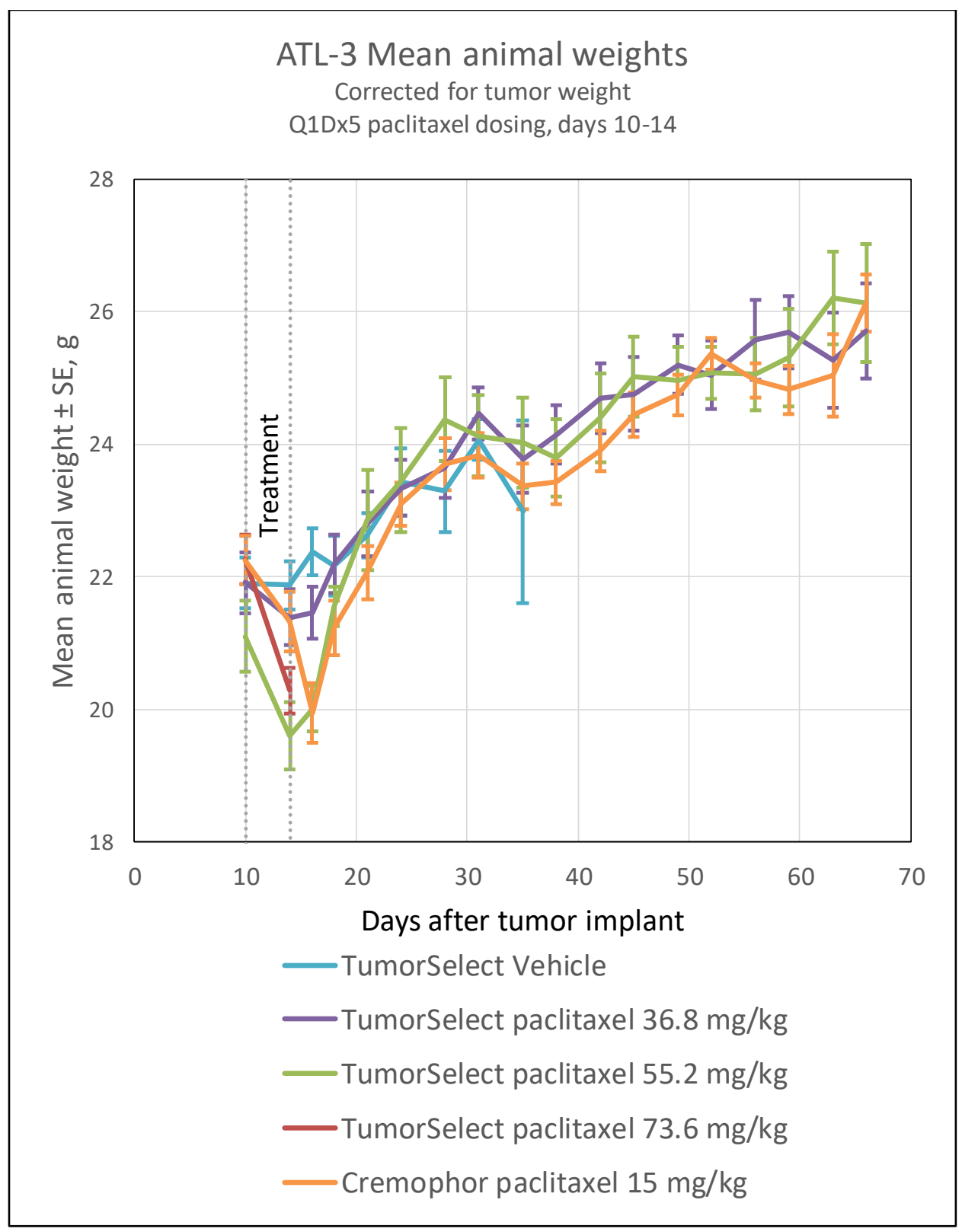

Figure 3 Mean animal weights in ATL-3

Figure 4 below shows mean tumor weights as a function of dose (expressed in paclitaxel equivalents). 


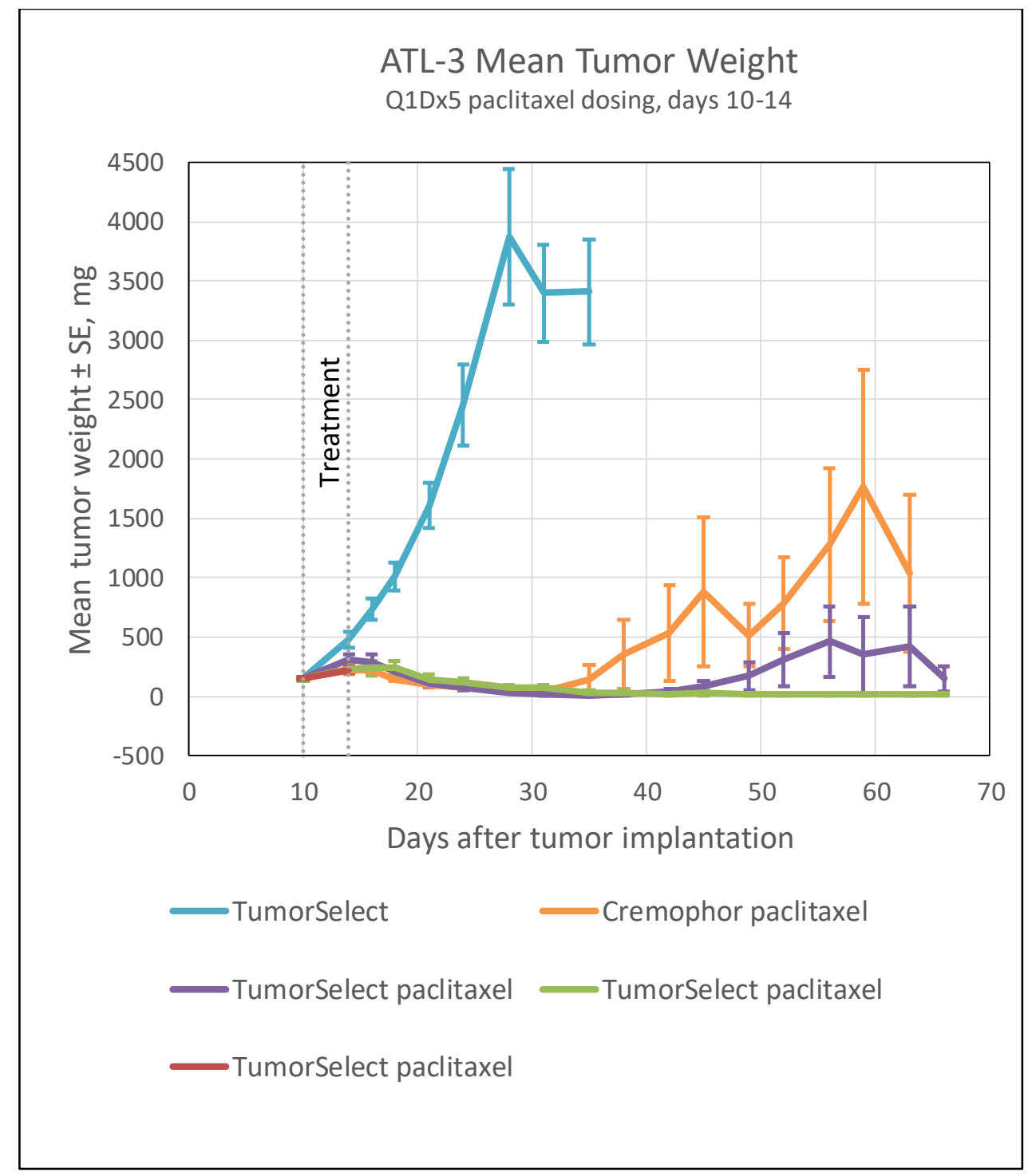

Figure 4 Mean tumor weights in ATL-3

ii. ATL-4\&5 Mouse breast-cancer xenograft drug distribution studies

Table 5 below provides the derived plasma and tissue pharmacokinetic data for 
Table 5 Plasma and tissue pharmacokinetics in ATL-4

\begin{tabular}{|c|c|c|c|c|c|c|c|c|}
\hline \multicolumn{9}{|c|}{$\begin{array}{l}\text { Pharmacokinetic parameters calculated from plasma and tissue concentrations of } \\
\qquad \text { ART } 207 \text { and paclitaxel } \\
\text { Experiment ATL-4 / non-tumored mice }\end{array}$} \\
\hline Treatment & Tissue & Analyte & $\begin{array}{c}t_{\max }^{a} \\
\text { (hour) }\end{array}$ & $\begin{array}{c}C_{\max }^{b} \\
(\mu \mathrm{g} / \mathrm{mL} \\
\text { or } \mathrm{g}) \\
\end{array}$ & $\begin{array}{c}\mathrm{AUC}_{0-8}{ }^{\mathrm{C}} \\
(\mathrm{hr} \cdot \mu \mathrm{g} / \mathrm{mL} \\
\text { or } \mathrm{g})\end{array}$ & $\begin{array}{l}t_{1 / 2}^{d} \\
(h r)\end{array}$ & $\begin{array}{c}\mathrm{Cl}^{\mathrm{e}} \\
(\mathrm{mL} / \mathrm{hr} / \mathrm{kg})\end{array}$ & $\begin{array}{c}\mathrm{V}_{\mathrm{ss}}^{\mathrm{f}} \\
(\mathrm{mL} / \mathrm{kg})\end{array}$ \\
\hline \multirow{10}{*}{ TumorSelect ${ }^{\circledR}$} & \multirow{2}{*}{ Plasma } & ART-207 & 0.083 & 640 & 2794 & 2.8 & 22.0 & 88.0 \\
\hline & & Paclitaxel & 1 & 2.237 & 14.4 & 11.5 & NA & NA \\
\hline & \multirow{2}{*}{ Brain } & ART-207 & 0.5 & 11.0 & 38.5 & NA & NA & NA \\
\hline & & Paclitaxel & 1 & 0.070 & 0.437 & NA & NA & NA \\
\hline & \multirow{2}{*}{ Heart } & ART-207 & 1 & 156 & 928 & NA & NA & NA \\
\hline & & Paclitaxel & 8 & 2.08 & 13.6 & NA & NA & NA \\
\hline & \multirow{2}{*}{ Liver } & ART-207 & 8 & 444 & 2354 & NA & NA & NA \\
\hline & & Paclitaxel & 8 & 13.2 & 80.6 & NA & NA & NA \\
\hline & \multirow{2}{*}{ Lungs } & ART-207 & 0.083 & 111 & 614 & NA & NA & NA \\
\hline & & Paclitaxel & 1 & 3.61 & 27.9 & NA & NA & $\mathrm{NA}$ \\
\hline \multirow{5}{*}{ Cremophor $^{\circledast}$} & Plasma & Paclitaxel & 0.083 & 32.9 & 37.7 & 1.0 & 500 & 658 \\
\hline & Brain & Paclitaxel & 0.5 & 0.301 & 1.31 & NA & NA & NA \\
\hline & Heart & Paclitaxel & 0.083 & 19.5 & 33.9 & NA & NA & NA \\
\hline & Liver & Paclitaxel & 1 & 81.4 & 283 & NA & NA & NA \\
\hline & Lungs & Paclitaxel & 1 & 47.9 & 93.7 & NA & $\mathrm{NA}$ & NA \\
\hline \multicolumn{9}{|c|}{$\begin{array}{l}{ }^{a} t_{\max }-\text { time at which maximum level seen } \\
{ }^{b} c_{\max }-\text { maximum level seen } \\
{ }_{8} \text { - area under the 0-8 hour concentration-time curve } \\
{ }^{d} t_{1 / 2}-\text { plasma elimination half-life } \\
{ }^{e} \mathrm{Cl}-\text { plasma clearance } \\
{ }^{f} V_{s s}-\text { volume of distribution at steady state }\end{array}$} \\
\hline
\end{tabular}

Table 6 below shows the derived plasma and tissue pharmacokinetic data for Study

ATL-5. 
Table 6 Plasma and tissue pharmacokinetics in ATL-5

\begin{tabular}{|c|c|c|c|c|c|c|c|c|}
\hline \multicolumn{9}{|c|}{$\begin{array}{l}\text { Pharmacokinetic parameters calculated from plasma and tissue/tumor concentrations of } \\
\text { ART } 207 \text { and Paclitaxel } \\
\text { Experiment ATL-5 / tumored mice }\end{array}$} \\
\hline Treatment & Tissue & Analyte & $\begin{array}{l}\operatorname{Tmax}^{\mathrm{a}} \\
\text { (hour) }\end{array}$ & $\begin{array}{l}\mathrm{Cmax}^{\mathrm{b}} \\
(\mu \mathrm{g} / \mathrm{mL} \\
\text { or } \mathrm{g})\end{array}$ & $\begin{array}{l}\text { AUClast } \\
\text { (hr· } \mu \mathrm{g} / \mathrm{mL} \\
\quad \text { or g) }\end{array}$ & $\begin{array}{l}\mathrm{t} 1 / 2 \\
(\mathrm{hr})\end{array}$ & $\begin{array}{c}\mathrm{Cl}^{\mathrm{e}} \\
(\mathrm{mL} / \mathrm{hr} / \mathrm{kg})\end{array}$ & $\begin{array}{c}\mathrm{V}_{\mathrm{ss}}^{\mathrm{f}} \\
(\mathrm{mL} / \mathrm{kg})\end{array}$ \\
\hline \multirow{12}{*}{ TumorSelect $^{\circledR}$} & \multirow{2}{*}{ Plasma } & ART-207 & 0.083 & 687 & 2309 & 2.6 & 26.0 & 97.0 \\
\hline & & Paclitaxel & 0.083 & 1.77 & 9.08 & 9.2 & NA & NA \\
\hline & \multirow{2}{*}{ Brain } & ART-207 & 0.083 & 12.5 & 41.8 & NA & NA & NA \\
\hline & & Paclitaxel & 0.083 & 0.045 & 0.220 & NA & NA & NA \\
\hline & \multirow{2}{*}{ Heart } & ART-207 & 1 & 171 & 926 & NA & NA & NA \\
\hline & & Paclitaxel & 0.5 & 1.39 & 10.1 & NA & NA & NA \\
\hline & \multirow{2}{*}{ Liver } & ART-207 & 8 & 438 & 2106 & NA & NA & NA \\
\hline & & Paclitaxel & 0.083 & 14.2 & 68.1 & NA & NA & NA \\
\hline & \multirow{2}{*}{ Lungs } & ART-207 & 0.5 & 109 & 631 & NA & NA & NA \\
\hline & & Paclitaxel & 1 & 3.61 & 27.6 & NA & NA & NA \\
\hline & \multirow{2}{*}{ Tumor } & ART-207 & 4 & 41.6 & 279 & NA & NA & NA \\
\hline & & Paclitaxel & 4 & 6.06 & 32.0 & NA & NA & NA \\
\hline \multirow{6}{*}{ Cremophor $^{\circledR}$} & Plasma & Paclitaxel & 0.083 & 41.6 & 34.4 & 1.0 & 547 & 567 \\
\hline & Brain & Paclitaxel & 0.083 & 0.600 & 1.51 & NA & NA & NA \\
\hline & Heart & Paclitaxel & 0.083 & 18.8 & 27.9 & NA & NA & NA \\
\hline & Liver & Paclitaxel & 0.083 & 92.9 & 254 & NA & NA & NA \\
\hline & Lungs & Paclitaxel & 1 & 79.2 & 120 & NA & NA & NA \\
\hline & Tumor & Paclitaxel & 8 & 3.97 & 18.9 & NA & NA & NA \\
\hline \multicolumn{9}{|c|}{$\begin{array}{l}{ }^{a} t_{\max }-\text { time at which maximum level seen } \\
{ }^{b} c_{\max }-\text { maximum level seen } \\
{ }^{8} \text { - area under the } 0-8 \text { hour concentration-time curve } \\
{ }^{d} t_{t_{1 / 2}-} \text { plasma elimination half-life } \\
{ }^{e} \mathrm{Cl}-\text { plasma clearance } \\
{ }^{f} V_{s s}-\text { volume of distribution at steady state }\end{array}$} \\
\hline
\end{tabular}

Figure 5 below shows the free paclitaxel eight-hour plasma, tissue, and tumor

AUCs obtained in Studies ATL-4 and ATL-5. 


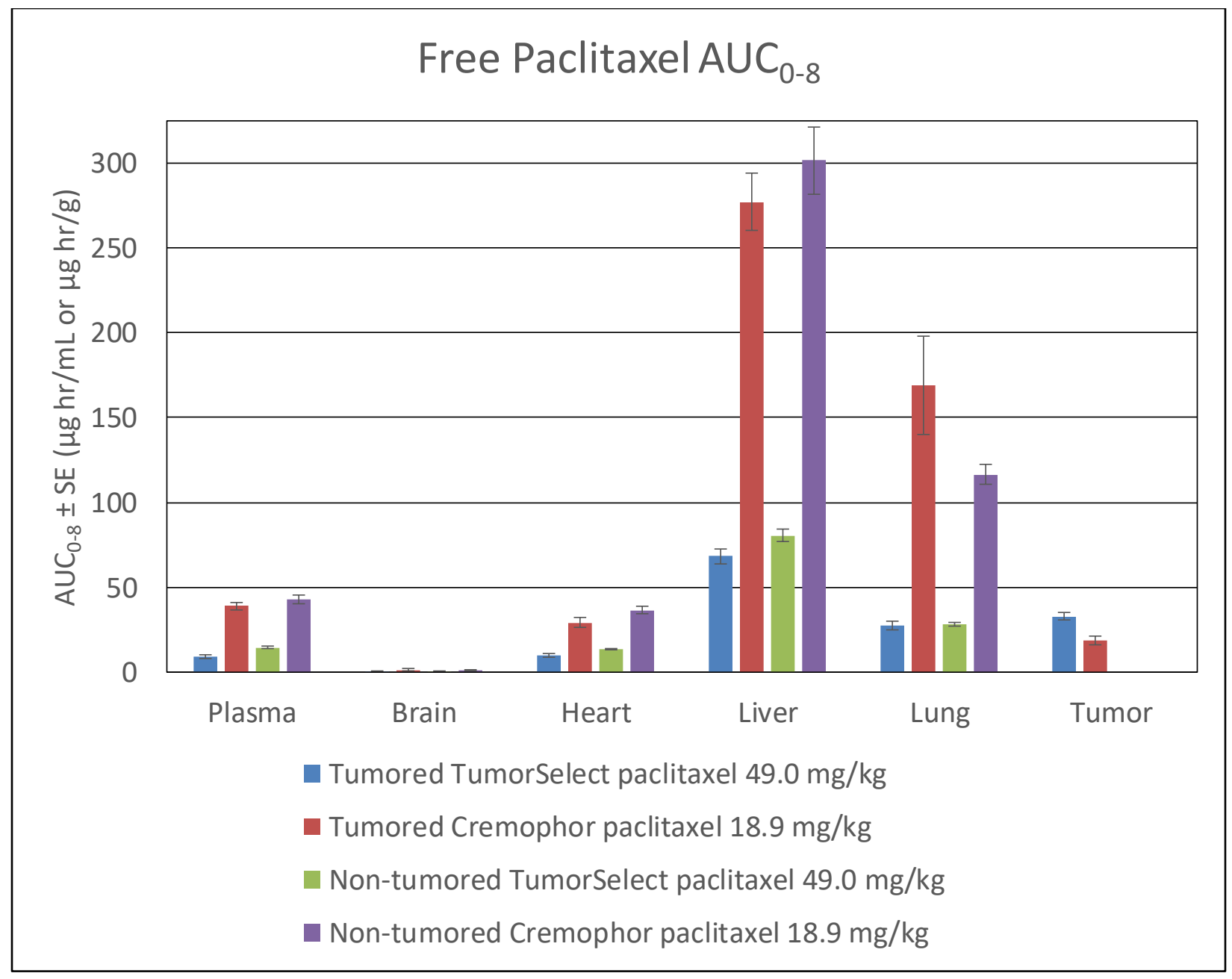

Figure 5 AUCs in ATL-4 and ATL-5

Difference between free paclitaxel levels of tumored mice injected with Taxol (paclitaxel) or TumorSelect ${ }^{\circledR}$ paclitaxel was significant for all assessed tissues $(\mathrm{p}<$ 0.05).

As illustrated in Figure 6 below, in Study ATL-5, tumor concentrations of free active paclitaxel are significantly higher from TumorSelect ${ }^{\circledR}$ paclitaxel than those 


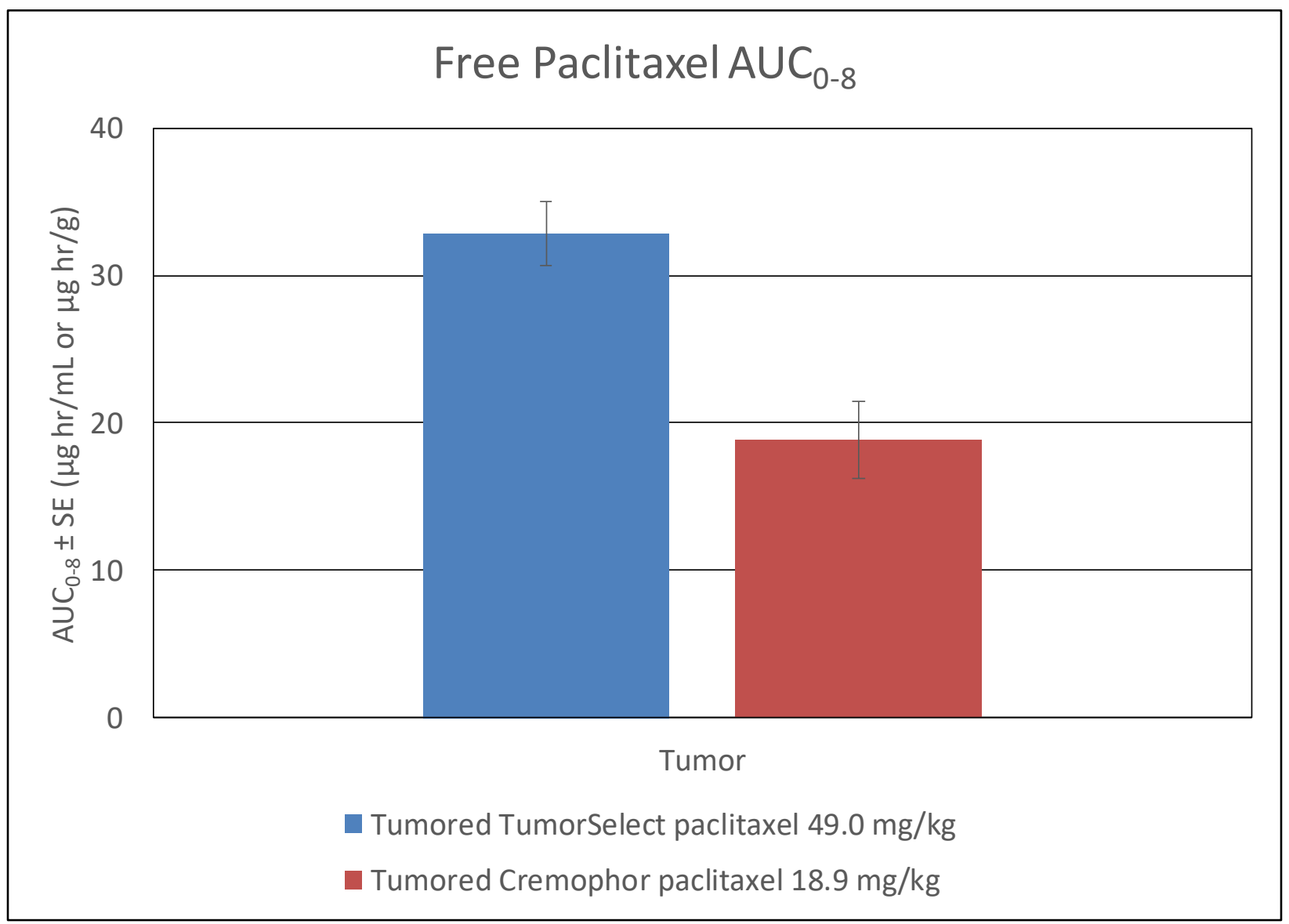

Figure 6 Paclitaxel tumor AUCs in study ATL-5 As seen in Figure 7 below, plasma and heart concentrations of free paclitaxel are significantly lower $(<80 \%)$ in tumored vs. non-tumored animals in those animals receiving TumorSelect ${ }^{\circledR}$ Paclitaxel.: (ATL4\&5) 


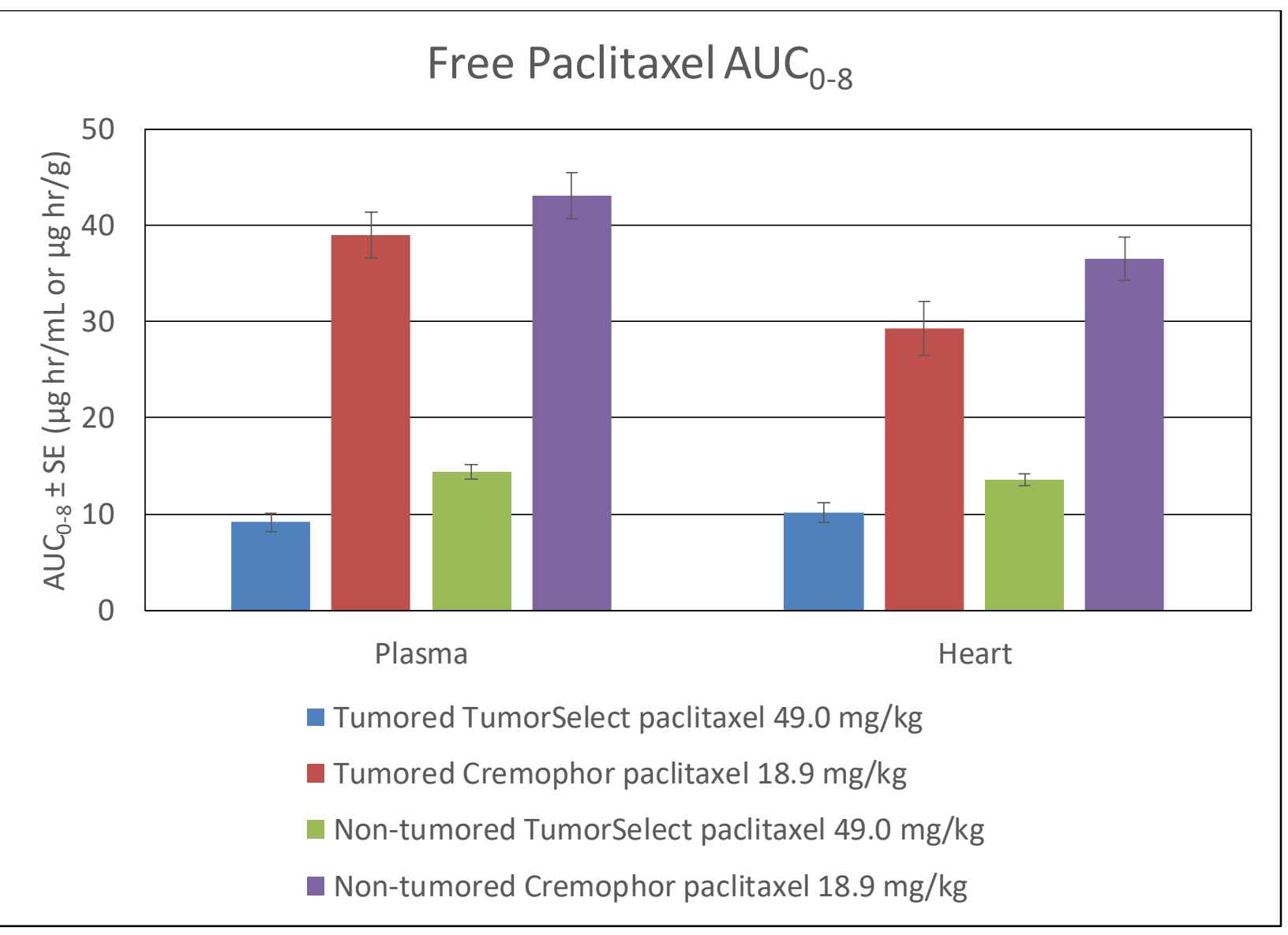

Figure 7 Plasma and heart AUCs in ATL-4 and ATL-5 model ART-207 and of paclitaxel delivered by by the Cremophor ${ }^{\circledR} / \mathrm{EtOH}$ formulation in Studies ATL-4 and 5.

Table 7 Volumes of distribution in ATL-4 and ATL-5

\begin{tabular}{|c|c|c|}
\hline \multicolumn{3}{|c|}{$\begin{array}{c}\text { Volume of distribution } \\
\mathrm{mL} / \mathrm{kg}\end{array}$} \\
\hline & $\begin{array}{c}\text { TumorSelect } \\
\text { paclitaxel prodrug }\end{array}$ & $\begin{array}{c}\text { Cremophor }^{(\mathbb{R}} / \text { Ethanol } \\
\text { paclitaxel }\end{array}$ \\
\hline Non-tumored mice & 88 & 658 \\
\hline Tumored mice & 97 & 567 \\
\hline
\end{tabular}


This parameter shows that TumorSelect ${ }^{\circledR}$ paclitaxel remains in the vasculature and does not indiscriminately distribute the toxic chemotherapeutic to normal tissues and organs as does Taxol ${ }^{\circledR}$.

\section{iii. Mouse pancreatic tumor xenograft}

In the pancreatic cancer model, the following was observed:

\section{a. Animal weights}

Figure 8 below shows the mean animal weights from the day of implantation through day 105 . Each point on the curves represents mean animal weight $( \pm \mathrm{SE})$ of each drug- and vehicle-treated group at the day of assessment. The mean group cutoff is five animals per group. 


\section{Mouse Xenograft MIA PaCa-2 Pancreatic Tumor \\ Q1Dx5 dosing}

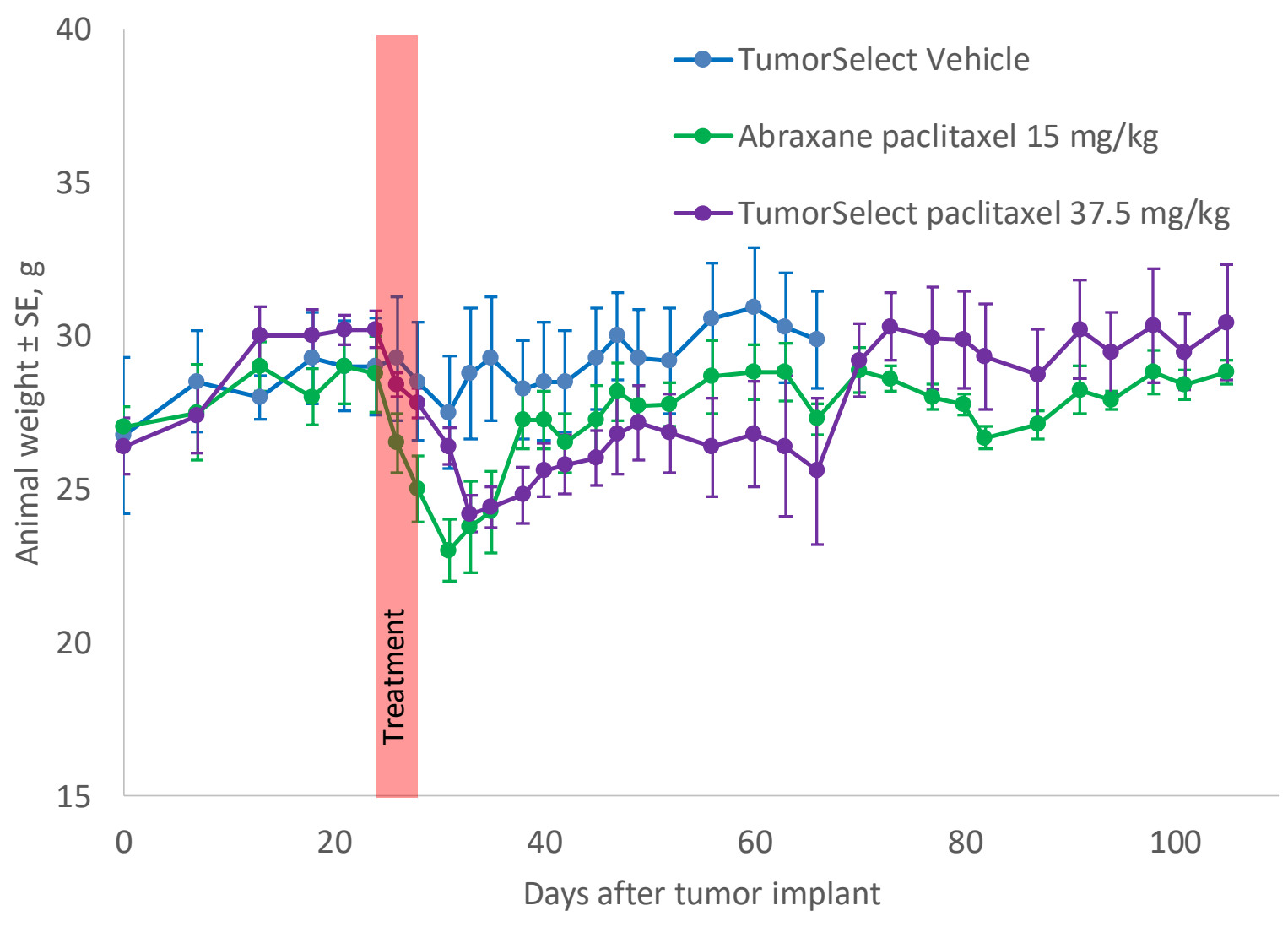

Figure 8 Mean animal weights in pancreatic tumor xenograft study

\section{b. Tumorgrowth}

Figure 9 below shows the mean tumor volumes from the day of implantation

through day 105. Each point on the curves represents mean tumor volume $( \pm \mathrm{SE})$

of each drug- and vehicle-treated group at the day of assessment. The mean group cutoff is five animals per group. It can be seen that tumors began to regrow at about 25 days post dosing following exposure to Abraxane ${ }^{\circledR}$ but continued to decrease in size for nearly an additional 30 days following the single exposure to TumorSelect ${ }^{\circledR}$ paclitaxel. 


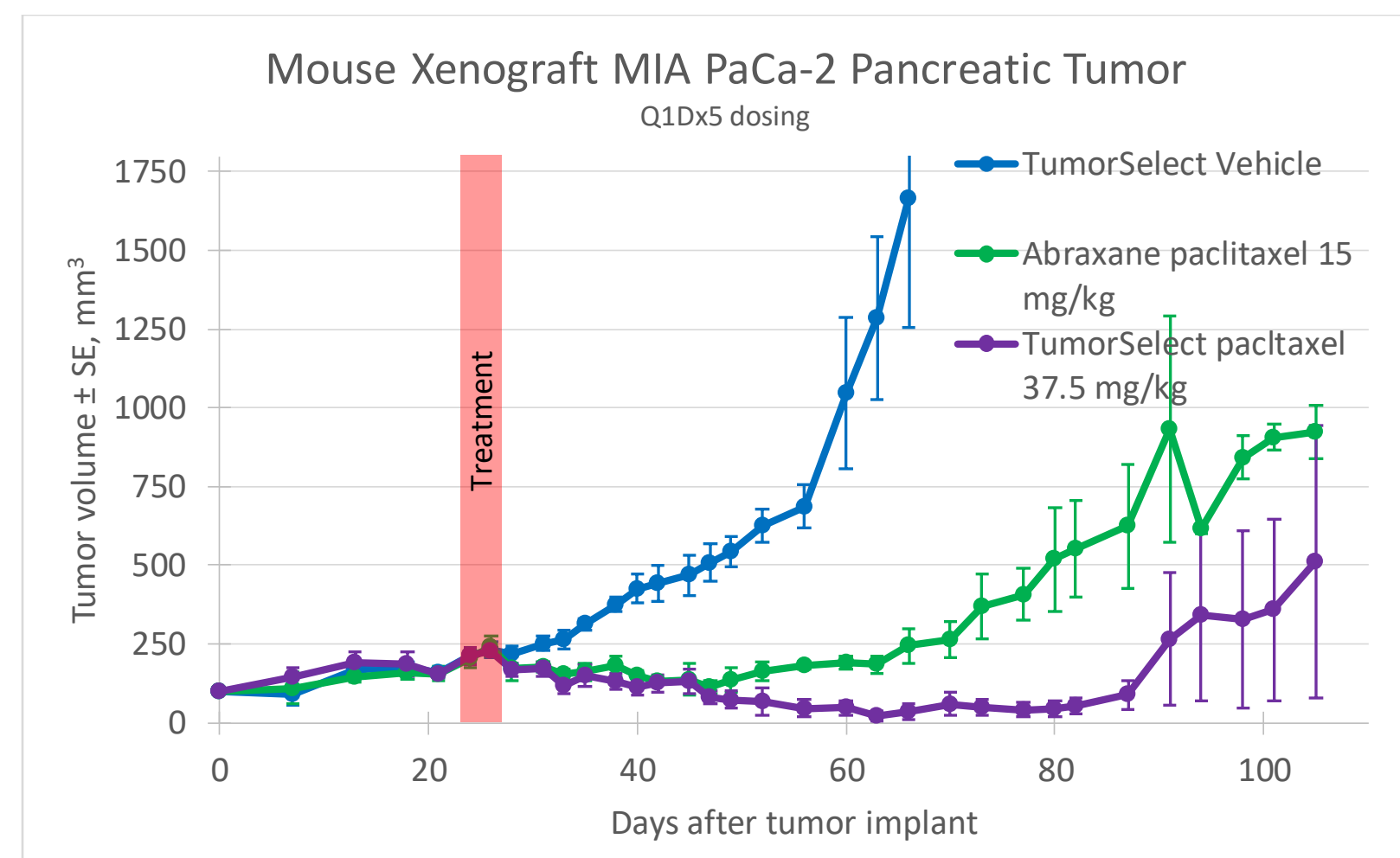

Figure 9 Mean tumor weights in pancreatic tumor xenograft study

6. Discussion

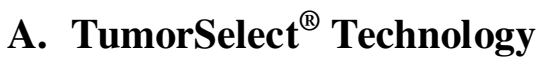

"Cancer cells rewire their metabolism to meet the energetic and biosynthetic demands of their high proliferation rates and environment." ${ }^{, 54}$ They are voracious consumers of cholesterol, triglycerides and phospholipids. ${ }^{55}$ Those essential nutrients are available to be taken up from LDL particles in the plasma. As a result, tumors dramatically overexpress LDL receptors (LDLR) by as much as eleven-fold relative to normal healthy systemic tissues. ${ }^{56,57}$ High LDLR expression is associated with rapid tumor growth ${ }^{58,59}$ and a poor prognosis for the patient. ${ }^{60,61,62,63}$ Incorporating chemotherapeutics into pseudo-LDL 
nanoparticles for delivery via overexpressed LDL receptors provides the opportunity for

2 selective delivery of lipophilic chemotherapeutics to tumors compared with normal tissues.

3 Pseudo-LDL particles can increase the utility of clinically approved chemotherapeutic

4 agents by altering their PK/PD properties and dramatically raising their therapeutic indices.

5 In order to incorporate the current clinically approved chemotherapeutic into the pseudo-

6 LDL particle, the hydrophilic chemotherapeutic (selected to be hydrophilic in order to be

7 administered by intravenous infusion in aqueous infusion fluids) is necessarily converted to

8 a lipophilic metabolically labile prodrug which will be retained within the pseudo-LDL

9 particle until the particle is internalized into the tumor cells by uptake by the LDL receptor

10 and processed by the endosome/lysosome cascade. This strategy is directly applicable to the

11 majority of clinically approved and widely utilized chemotherapeutics.

12 The proposed mechanism for the cleavage of the promoiety from ART-207, and liberation

13 of paclitaxel, in the acidic environment of the endosome/lysosome cascade is shown in

14 Figure 10 below. This hydrolysis which takes place intracellularly delivers the active

15 cytotoxic, paclitaxel, and the lipophilic promoiety is cleaved to the nontoxic products,

16 carbon dioxide, glycerol, and oleoyl aldehyde which is rapidly transformed to the fatty acid

$17 \quad$ oleic acid. 

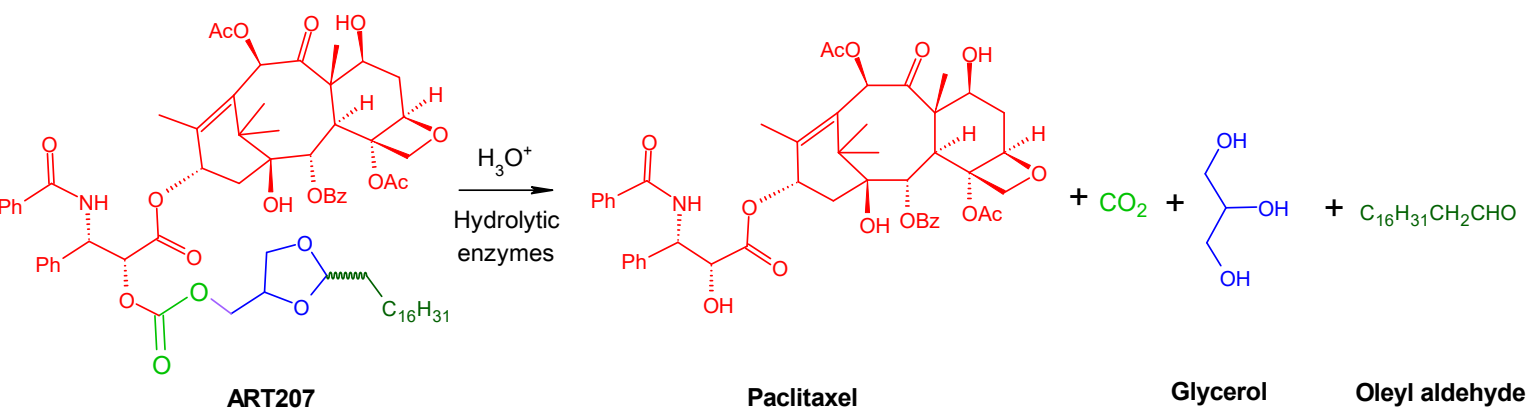

Veiled Therapeutics has developed the strategy as TumorSelect ${ }^{\circledR}$ technology and licensed TumorSelect $^{\circledR}$ Paclitaxel to Cloaked Therapeutics Development, LLC to demonstrate its utility of promise to improve both cytotoxic chemotherapy efficacy and tolerability when compared with standard generic Cremophor ${ }^{\circledR}$ as well as Abraxane ${ }^{\circledR}$ formulations of paclitaxel. Since many of paclitaxel's issues can be traced to its well-characterized PK/PD limitations, investigators expect that improvements in paclitaxel's PK/PD profile should translate to improved clinical outcomes. TumorSelect ${ }^{\circledR}$ paclitaxel has overcome the limitations of conventional paclitaxel delivery systems as demonstrated by its superior efficacy and apparent lack of toxicity in established preclinical in vivo mouse models of breast cancer and pancreatic cancer. These experimentally observed benefits support the validity of the TumorSelect ${ }^{\circledR}$ technology and strategy.

\section{7. Conclusions}

15 The future of traditional cytotoxic chemotherapy:

16 Clinical practice for the foreseeable future will continue to rely on cytotoxic chemotherapy with

17 hundreds of thousands of patients treated annually. Also, it is clear from recently published

18 studies, such as the NEJM atezolizumab plus Abraxane ${ }^{\circledR}$ in triple negative breast cancer study, ${ }^{40}$ 
1 that traditional chemotherapy will remain a mainstay of cancer treatment for the foreseeable

2 future. In particular, there is evidence that taxanes can potentiate immunotherapy. ${ }^{64}$

3 Abraxane ${ }^{\circledR}$ upon administration allows for a higher fraction of free paclitaxel than even generic

4 Cremophor $^{\circledR}$ paclitaxel and thus drives wider tissue distribution than standard paclitaxel. ${ }^{65}$

5 Albumin-bound drug may leave capillaries by active transport across vessel walls, but there is

6 little or no active uptake into tumors and thus little or no selectivity for tumor cells. In short,

7 with Abraxane ${ }^{\circledR}$ both normal and tumor tissue are non-selectively exposed to free paclitaxel.

8 Abraxane ${ }^{\circledR}$, s pharmacokinetic "improvements" are the direct opposite of those that are

9 theoretically desired, and thus opposite to those seen with the superior TumorSelect ${ }^{\circledR}$ paclitaxel

10 formulation. TumorSelect ${ }^{\circledR}$ dramatically decreases normal tissue exposure while selectively

11 increasing tumor exposure.

12 Abraxane $^{\circledR}$ and TumorSelect ${ }^{\circledR}$ paclitaxel were compared in both a pancreatic and an ovarian

13 model with results similar to the Cremophor ${ }^{\circledR}$ paclitaxel results. However, TumorSelect ${ }^{\circledR}$

14 paclitaxel was better tolerated than standard generic Cremophor ${ }^{\circledR}$ paclitaxel or Abraxane ${ }^{\circledR}$ and

15 can be dosed more intensively (2.5 equivalents of the MTD in mice of either Cremophor ${ }^{\circledR}$

16 paclitaxel or Abraxane ${ }^{\circledR}$ ) than either the generic Cremophor ${ }^{\circledR}$ paclitaxel or the Abraxane ${ }^{\circledR}$

17 formulation. In a tumored mouse model with various dose levels of TumorSelect ${ }^{\circledR}$ paclitaxel a

18 measure of weight loss post dosing, as an indication of toxicity, showed that TumorSelect ${ }^{\circledR}$

19 paclitaxel could be dosed at 2.5 equivalents of paclitaxel with minimal weight loss in the

20 animals, demonstrating that the TumorSelect ${ }^{\circledR}$ paclitaxel formulation was less toxic than

$21 \quad$ Abraxane $^{\circledR}$.

22 In addition to allowing more intense dosing due to lower systemic toxicity, the mechanism of 
1 receptor mediated uptake will bypass the common mechanism of resistance of $\mathrm{ABC}$ transporter

2 activity (PGP, MDR, etc.) which is membrane located. Both these attributes should enhance the

3 efficacy and reduce the systemic side effect toxicity of the chemotherapeutic agents.

4 The demonstrated advantages of TumorSelect ${ }^{\circledR}$ paclitaxel include:

5 - Better efficacy — in the animals treated with Abraxane ${ }^{\circledR}$, the tumors continued their steady growth, while in those treated with TumorSelect ${ }^{\circledR}$ paclitaxel (at 2.5X the paclitaxel equivalent of Abraxane ${ }^{\circledR}$ ) the tumors had nearly disappeared by the day 56 of study.

- Less toxicity—-there was substantially less weight loss observed in the animals treated with TumorSelect ${ }^{\circledR}$ paclitaxel at $2.5 \mathrm{X}$ the paclitaxel-equivalent dose given to Abraxane ${ }^{\circledR}$ treated animals.

11 Un like TumorSelect ${ }^{\circledR}$ paclitaxel, Abraxane ${ }^{\circledR}$ allows for a higher fraction of free paclitaxel and

12 thus drives wider tissue distribution than Cremophor ${ }^{\circledR}$-formulated paclitaxel. While tumor

13 response rates are improved, the debilitating side-effects of paclitaxel are also made substantially

14 worse. Nonetheless, Abraxane ${ }^{\circledR}$, which has never more than barely penetrated its total potential

15 market, has become a blockbuster commercial success with sales of nearly $\$ 1$ billion.

16 TumorSelect $^{\circledR}$ paclitaxel has the ideal and directly opposite PK/PD profile of Abraxane ${ }^{\circledR}$ and

17 would therefore be expected to improve tumor responses while substantially decreasing side18 effects.

\section{Additional TumorSelect ${ }^{\circledR}$ Advantages}

20 - It does not contain or require human proteins as part of its manufacturing process

21 - It is not a liposome technology and is comprised of well-known, safe, and easily sourced 

components

\section{8. Availability of data and materials}

\section{9. Abbreviations}

$4 \quad \mu \mathrm{L} \quad$ Microliter

$5 \mu \mathrm{m} \quad$ Micrometer

$6 \AA \quad$ Angstrom

7 ACS American Cancer Society

8 AUC Area under the concentration-time curve

9 BCRP Breast cancer resistance protein

10 CDC Centers for Disease Control and Prevention of the U.S. Department of Health \& Human

11 Services

12 CE Cholesterol oleate

13 DCM Dichloromethane

14 DMPC Dimyristoyllphosphatidylcholine

15 EtOH Ethanol

16 FC Free cholesterol

17 IV Intravenous 
$1 \quad \mathrm{~kg} \quad$ Kilogram

2 LC Liquid chromatography

3 LDL Low-density lipoprotein

4 LDLR Low-density lipoprotein receptor

$5 \quad$ LPM Lipid premix

$6 \mathrm{~m} / \mathrm{z} \quad$ Mass-to-charge ratio

7 MF $\quad$ MicroFluidizer ${ }^{\circledR}$

$8 \mathrm{mfg}$ Date of manufacturing

9 mg Milligram

$10 \mathrm{~mL}$ Milliliter

$11 \mathrm{~mm}$ Millimeter

12 MRP-1 Multi-drug resistance related protein

13 MS Mass spectrometry

14 MTD Maximum tolerated dose

15 NCI National Cancer Institute of the US National Institutes of Health, U.S. Department of

16 Health \& Human Services

$17 \mathrm{~nm}$ Nanometer 
$1 \quad$ P188 Poloxamer P188

2 PC Phosphatidylcholine

3 PD Pharmacodynamics

4 PD-1/PD-L1 Programmed death ligand 1

$5 \quad$ Pgp P-glycoprotein

6 PK Pharmacokinetics

$7 \quad$ Q1Dx5One dose every day for five days

8 SC Subcutaneous

9 SE Standard error

10 TG Soybean oil

11 TI Therapeutic index

$12 \mathrm{U}$ Ubiquinol 10

13 VitE Mixed tocopherols

14 WHO World Health Organization

15 10. Declarations 
 \\ B. Ethics approval}

All animal experimental procedures in Studies ATL 4 and ATL-5 were approved by the Institutional Animal Care and Use Committee of Southern Research. Animal laboratories of Southern Research are AAALAC accredited.

\section{Consent for publication}

Not applicable

\section{Availability of data and materials}

The datasets used and/or analyzed during the current study are available from the corresponding author on reasonable request.

\section{E. Competing interests}

The authors declare that they have no competing interests.

\section{F. Funding}

The work described in this paper was funded by Veiled Therapeutics, LLC (formerly Arbor Therapeutics, LLC) and by Cloaked Therapeutics, LLC.

\section{G. Author contributions}

JDM conceived the manuscript and edited the final draft. SJB wrote the manuscript and edited the final draft. IN and DLR performed significant portions of the formulation 
development work and edited the final draft. AW and MG designed and executed the chemical synthesis of ART-207, the lipophilic paclitaxel prodrug and edited the final draft of the manuscript. MC and DL prepared the TumorSelect ${ }^{\circledR}$ paclitaxel formulations used in the in vivo mouse model studies and edited the final draft of the manuscript. PPC and PP conceived and executed the in vivo mouse studies comparing TumorSelect ${ }^{\circledR}$ paclitaxel to Abraxane ${ }^{\circledR}$ and edited the final draft of the manuscript.

\section{References}

${ }^{1}$ Falzone L, Salomone S, Libra M. Evolution of Cancer Pharmacological Treatments at the Turn of the Third Millennium. Frontiers in Pharmacology 2018; 9:1300.

${ }^{2}$ Breedveld S, Craft D, van Haveren R, Heijmen B. Multi-criteria optimization and decisionmaking in radiotherapy. European Journal of Operational Research 2019; 277(1):1-19.

${ }^{3}$ National Cancer Institute. Surgery to Treat Cancer . Available from URL: https://www.cancer.gov/about-cancer/treatment/types/surgery, 08 Sep 2020

${ }^{4}$ World Health Organization. WHO Report on Cancer: Setting Priorities, Investing Wisely and Providing Care for All 2020. Available from URL:

https://apps.who.int/iris/rest/bitstreams/1267643/retrieve ; accessed 22 AUG 2020

5 American Cancer Society. Cancer Facts \& Figures 2020. Available from URL: https://www.cancer.org/research/cancer-facts-statistics/all-cancer-facts-figures/cancer-factsfigures-2020.html; accessed 22 AUG 2020

${ }^{6}$ Centers for Disease Control and Prevention. Health and Economic Costs of Chronic Diseases: Cancer 2020. Available from URL: https://www.cdc.gov/chronicdisease/about/costs/index.htm, accessed 24 AUG 2020

${ }^{7}$ Jönsson B. Cost of Cancer: Healthcare Expenditures and Economic Impact. In: Walter E, editor. Regulatory and Economic Aspects in Oncology Cham: Springer International Publishing; 2019. p. 7-23.

${ }^{8}$ Blue Matter Consulting. Oncology Trends: Is Past Performance Predictive of Future Returns? Part I, Trends Overview 2019. Available from URL: https://bluematterconsulting.com/oncologytrends-part-i-overview/ ;accessed 22 AUG 2020

${ }^{9}$ Jones S, Anagnostou V, Lytle K, Parpart-Li S, Nesselbush M, Riley DR, et al. Personalized genomic analyses for cancer mutation discovery and interpretation. Sci Trans1 Med 2015; 7(283):283.

${ }^{10}$ Nakagawa H, Fujita M. Whole genome sequencing analy sis for cancer genomics and precision medicine. Cancer Science 2018; 109(3):513-22. 
${ }^{11}$ Ding L, Bailey MH, Porta-Pardo E, Thorsson V, Colaprico A, Bertrand D, et al. Perspective on Oncogenic Processes at the End of the Beginning of Cancer Genomics. Cell 2018; 173(2):305-20.

${ }^{12}$ Friedman AA, Letai A, Fisher DE, Flaherty KT. Precision medicine for cancer with nextgeneration functional diagnostics. Nat Rev Cancer 2015; 15(12):747-56.

${ }^{13}$ Letai A. Functional precision cancer medicine-moving beyond pure genomics. Nature Medicine 2017; 23(9):1028-35.

${ }^{14}$ Sokolenko AP, Imyanitov EN. Molecular Diagnostics in Clinical Oncology. Frontiers in Molecular Biosciences 2018; 5:76.

15 Jelski W, Mroczko B. Biochemical diagnostics of pancreatic cancer - Present and future. Clinica Chimica Acta 2019; 498:47-51.

${ }^{16}$ Schwartzberg L, Kim ES, Liu D, Schrag D. Precision Oncology: Who, How, What, When, and When Not? American Society of Clinical Oncology Educational Book 2017(37):160-69.

${ }^{17}$ Nussinov R, Jang H, Tsai C-J, Cheng F. Review: Precision medicine and driver mutations: Computational methods, functional assays and conformational principles for interpreting cancer drivers. PLOS Computational Biology 2019; 15(3):e1006658.

${ }^{18}$ Blue Matter Consulting. Oncology Trends: Is Past Performance Predictive of Future Returns? - Part II, Unmet Needs \& Future Advancements 2019. Available from URL:

https://bluematterconsulting.com/part-ii-oncology-trends-unmet-needs-future/ ; accessed 22 AUG 2020

${ }^{19}$ Corrie PG. Cytotoxic chemotherapy: clinical aspects. Medicine Oncology: Part 1 of 22011 ; 39(12):717-22.

${ }^{20}$ Harvey RD, Khuri FR. Cytotoxic Chemotherapy. In: anonymous, editor. The American Cancer Society's Principles of Oncology; 2018. p. 220-235.

${ }^{21}$ Dickens E, Ahmed S. Principles of cancer treatment by chemotherapy. Surgery (Oxford) 2018; 36(3):134-38.

${ }^{22}$ DeVita VT, Chu E. A History of Cancer Chemotherapy. Cancer Research 2008; 68(21):8643 53.

${ }^{23}$ Goldberg KB, Blumenthal GM, McKee AE, Pazdur R. The FDA Oncology Center of Excellence and precision medicine. Experimental Biology and Medicine 2017; 243(3):308-12.

${ }^{24}$ Beaver JA, Howie LJ, Pelosof L, Kim T, Liu J, Goldberg KB, et al. A 25-Year Experience of US Food and Drug Administration Accelerated Approval of Malignant Hematology and Oncology Drugs and Biologics: A Review. JAMA Oncology 2018; 4(6):849-56.

${ }^{25}$ Zhou J, Vallejo J, Kluetz P, Pazdur R, Kim T, Keegan P, et al. Overview of Oncology and Hematology Drug Approvals at US Food and Drug Administration Between 2008 and 2016. JNCI: Journal of the National Cancer Institute 2019; 111(5):449-58.

${ }^{26}$ Oiseth SJ, Aziz MS. Cancer immunotherapy: a brief review of the history, possibilities, and challenges ahead. Journal of Cancer Metastasis and Treatment 2017; 3:250-61. 
${ }^{27}$ Waldman AD, Fritz JM, Lenardo MJ. A guide to cancer immunotherapy: from T cell basic science to clinical practice. Nature Reviews Immunology 2020. https://doi.org/10.1038/s41577020-0306-5.

${ }^{28}$ National Cancer Institute. Targeted Therapy to Treat Cancer . Available from URL: https://www.cancer.gov/about-cancer/treatment/types/targeted-therapies, 08 Sep 2020

${ }^{29}$ National Cancer Institute. Hormone Therapy to Treat Cancer . Available from URL: https://www.cancer.gov/about-cancer/treatment/types/hormone-therapy, 08 Sep 2020

${ }^{30}$ Mikuła-Pietrasik J, Witucka A, Pakuła M, Uruski P, Begier-Krasińska B, Niklas A, et al. Comprehensive review on how platinum- and taxane-based chemotherapy of ovarian cancer affects biology of normal cells. Cellular and Molecular Life Sciences 2019; 76(4):681-97.

${ }^{31}$ Mansinho A, Boni V, Miguel M, Calvo E. New designs in early clinical drug development. Annals of Oncology 2019; 30(9):1460-65.

32 Therapeutic Index, https://toxtutor.nlm.nih.gov/02-005.html, accessed 28 AUG 2020

${ }^{33}$ Hait WN, Rubin E, Bertino JR. 46 - Cancer Therapeutics. In: Mendelsohn J, Gray JW, Howley PM, Israel MA, Thompson CB, editors. The Molecular Basis of Cancer (Fourth Edition) Philadelphia 2015 p.635-50.e1.

${ }^{34}$ Lee HT, Lee JY, Lim H, Lee SH, Moon YJ, Pyo HJ, et al. Molecular mechanism of PD-1/PDL1 blockade via anti-PD-L1 antibodies atezolizumab and durvalumab. Scientific Reports 2017; 7(1):5532. https://doi.org/10.1038/s41598-017-06002-8

${ }^{35}$ Liu B, Song Y, Liu D. Recent development in clinical applications of PD-1 and PD-L1 antibodies for cancer immunotherapy. Journal of Hematology \& Oncology 2017; 10(1):174.

${ }^{36}$ Zhang T, Xie J, Arai S, Wang L, Shi X, Shi N, et al. The efficacy and safety of anti-PD-1/PDL1 antibodies for treatment of advanced or refractory cancers: a meta-analysis. Oncotarget 2016; 7(45):73068-79.

${ }^{37}$ Jiang Y, Chen M, Nie H, Yuan Y. PD-1 and PD-L1 in cancer immunotherapy: clinical implications and future considerations. Human Vaccines \\& Immunotherapeutics 2019; 15(5):1111-22.

${ }^{38}$ Sun JY, Zhang D, Wu S, Xu M, Zhou X, Lu X-J, et al. Resistance to PD-1/PD-L1 blockade cancer immunotherapy: mechanisms, predictive factors, and future perspectives. Biomarker Research 2020; 8(1):35.

${ }^{39}$ McArthur H, Page D. Immunotherapy for the treatment of breast cancer: Checkpoint blockade, cancer vaccines, and future directions in combination immunotherapy. Clinical Advances in Hematology \& Oncology 2016; 14:922-33.

${ }^{40}$ Schmid P, Adams S, Rugo HS, Schneeweiss A, Barrios CH, Iwata H, et al. Atezolizumab and Nab-Paclitaxel in Advanced Triple-Negative Breast Cancer. New England Journal of Medicine N Engl J Med 2018; 379(22):2108-21.

${ }^{41}$ Liu W, Zhang L, Xiu Z, Guo J, Wang L, Zhou Y, et al. Combination of Immune Checkpoint Inhibitors with Chemotherapy in Lung Cancer. Onco Targets Ther 2020; 13:7229-41. 
${ }^{42}$ Bailly C, Thuru X, Quesnel B. Combined cytotoxic chemotherapy and immunotherapy of cancer: modern times. NAR Cancer 2020; 2(1).

${ }^{43}$ Firestone RA. Low-density lipoprotein as a vehicle for targeting antitumor compounds to cancer cells. Bioconjug Chem 1994; 5(2):105-13.

${ }^{44}$ Harisa GI, Alanazi FK. Low density lipoprotein bionanoparticles: From cholesterol transport to delivery of anti-cancer drugs. Saudi Pharmaceutical Journal 2014; 22(6):504-15.

${ }^{45}$ Caruso MG, Osella AR, Notarnicola M, Berloco P, Leo S, Bonfiglio C, et al. Prognostic value of low density lipoprotein receptor expression in colorectal carcinoma. Oncology Reports 1998; 5(4):927-57.

${ }^{46}$ Guillaumond F, Bidaut G, Ouaissi M, Servais S, Gouirand V, Olivares O, et al. Cholesterol uptake disruption, in association with chemotherapy, is a promising combined metabolic therapy for pancreatic adenocarcinoma. Proceedings of the National Academy of Sciences 2015; 112(8):2473-78.

${ }^{47}$ Vasseur S, Guillaumond F. LDL Receptor: An open route to feed pancreatic tumor cells. Mol Cell Oncol 2015; 3(1):e1033586-88.

${ }^{48}$ Gallego-Jara J, Lozano-Terol G, Sola-Martínez RA, Cánovas-Díaz M, de Diego Puente T. A Compressive Review about Taxol(®): History and Future Challenges. Molecules 2020; 25(24).

${ }^{49}$ McChesney JD, Nikoulin I, Bannister SJ, Rodenburg DL, Inventors; Veiled Therapeutics, LLC, assignee. Nanoparticulate Compositions for Targeted Delivery of Acid Labile, Lipophilic Prodrugs of Cancer Chemotherapeutics and Their Preparation. US patent 10,064,823 B2. 2018.

${ }^{50}$ McChesney JD, Henri JT, Venkataraman SK, Gundluru MK, Inventors; Veiled Therapeutics, LLC, assignee. Acid-Labile Lipophilic Prodrugs of Cancer Chemotherapeutic Agents. US patent 8,440,714 B2. 2013.

${ }^{51}$ Alexander MS, Kiser MM, Culley T, Kern JR, Dolan JW, McChesney JD, et al. Measurement of paclitaxel in biological matrices: high-throughput liquid chromatographic-tandem mass spectrometric quantification of paclitaxel and metabolites in human and dog plasma. Journal of Chromatography B 2003; 785(2):253-61.

52 Bailer AJ. Testing for the equality of area under the curves when using destructive measurement techniques. Journal of Pharmacokinetics and Biopharmaceutics 1988; 16(3):30309.

${ }^{53}$ Holder, Daniel J., Hsuan F, Dixit R, Soper K. A Method For Estimating and Testing Area Under the Curve In Serial Sacrifice, Batch, and Complete Data Designs. Journal of Biopharmaceutical Statistics 1999; 9(3):451-64.

${ }^{54}$ Garcia-Bermudez J, Williams RT, Guarecuco R, Birsoy K. Targeting extracellular nutrient dependencies of cancer cells. Molecular Metabolism 2020; 33:67-82.

${ }^{55}$ Huang J, Lena Li, Lian J, Schauer S, Vesely P, Kratky D, et al. Tumor-Induced Hyperlipidemia Contributes to Tumor Growth. Cell Reports 2016; 15(2):336-48.

${ }^{56}$ Firestone RA. Low-Density Lipoprotein as a Vehicle for Targeting Antitumor Compounds to Cancer Cells. Bioconjugate Chemistry 1994; 5(2):105-13. 
${ }^{57}$ Antalis CJ, Uchida A, Buhman KK, Siddiqui RA. Migration of MDA-MB-231 breast cancer cells depends on the availability of exogenous lipids and cholesterol esterification. Clinical \& Experimental Metastasis 2011; 28(8):733-41.

${ }^{58}$ Gallagher EJ, Zelenko Z, Neel BA, Antoniou IM, Rajan L, Kase N, et al. Elevated tumor LDLR expression accelerates LDL cholesterol-mediated breast cancer growth in mouse models of hyperlipidemia. Oncogene 2017; 36(46):6462-71.

59 Zhou T, Zhan J, Fang W, Zhao Y, Yang Y, Hou X, et al. Serum low-density lipoprotein and low-density lipoprotein expression level at diagnosis are favorable prognostic factors in patients with small-cell lung cancer (SCLC). BMC Cancer 2017; 17(1):269.

${ }^{60}$ Caruso MG, Osella AR, Notarnicola M, Berloco P, Leo S, Bonfiglio C, et al. Prognostic value of low density lipoprotein receptor expression in colorectal carcinoma. Oncology Reports 1998; 5(4):927-57.

${ }^{61}$ Göbel A, Rauner M, Hofbauer LC, Rachner TD. Cholesterol and beyond - The role of the mevalonate pathway in cancer biology. Biochimica et Biophysica Acta (BBA) - Reviews on Cancer 2020; 1873(2):188351.

${ }^{62}$ Guillaumond F, Bidaut G, Ouaissi M, Servais S, Gouirand V, Olivares O, et al. Cholesterol uptake disruption, in association with chemotherapy, is a promising combined metabolic therapy for pancreatic adenocarcinoma. Proceedings of the National Academy of Sciences 2015; 112(8):2473-78.

${ }^{63}$ Floeth, M., Elges, S., Gerss, J., Schwöppe, C., Kessler, T., Herold, T., Wardelmann, E., Berdel, W.E., Lenz, G., Mikesch, J.-H., Hartmann, W., Schliemann, C. and Angenendt, L. (2020), Low-density lipoprotein receptor (LDLR) is an independent adverse prognostic factor in acute myeloid leukaemia. Br J Haematol, doi:10.1111/bjh.16853

${ }^{64}$ Bailly C, Thuru X, Quesnel B. Combined cytotoxic chemotherapy and immunotherapy of cancer: modern times. NAR Cancer 2020; 2(1).

${ }^{65}$ Abraxane package insert, Section 12.3 Pharmacokinetics, available at https://www.abraxanepro.com/, accessed 11 Feb 2021. 